\title{
Kitlesel Gözetime Karşı Kolektif Bir Üretim Biçimi Olarak Sızıntı Gazeteciliği \\ Behlül ÇALIŞKAN
}

doktor, araştırma görevlisi, marmara üniversitesi, iletişim fakültesi behlul.caliskan@marmara.edu.tr

\begin{abstract}
Leaking Journalism as a form of Peer Production Against Mass Surveillance

The objective of the study is to suggest a conceptualization of leaking journalism as a network-based journalism practice that includes the process of acquiring and publishing of information leaks. The study also aims to explain the possibilities of resistance that leaking journalism offers as a form of peer-production against mass surveillance. In this context, the information leak actions such as Pentagon Papers and Cablegate that shifted the way of world politics, and changes in the power structure caused by these actions are examined from a historical perspective. Subsequently, citizen journalism and network journalism approaches, which can be seen as the precursor of the practice of leaking journalism, are described and the leaking journalism model is defined. Finally, the argument that leaking journalism create a form of peer-production against mass surveillance is discussed within the scope of counter-surveillance and commons-based peer production approaches.
\end{abstract}

keywords: Information leaks, leaking journalism, countersurveillance, peer-production 


\section{Résumé}

\section{Le journalisme base sur la fuite d'information comme forme de production par les pairs contre la surveillance de masse}

L'objectifde cetarticle est de suggérer une conceptualisation dujournalisme basé sur la fuite d'information comme une pratique de journalisme basé sur le réseau qui comprend le processus d'acquisition et de publication de fuites d'informations. L'article vise également à expliquer les possibilités de résistance que le journalisme basé sur la fuite d'information offre comme une forme de production par les pairs contre la surveillance de masse. Dans ce contexte, les actions de fuite d'information telles que Pentagon Papers et Cablegate qui ont un effet signifiant sur la politique mondiale, et les changements dans la structure de pouvoir causés par ces actions sont examinés d'un point de vue historique. Par la suite, les approches du journalisme citoyen et du journalisme en réseau, qui peuvent être perçues comme le précurseur de la pratique du journalisme basé sur la fuite d'information sont décrites, et le modèle de journalisme basé sur la fuite d'information est défini. Enfin, l'argument selon lequel le journalisme basé sur la fuite d'information crée une forme de production par les pairs contre la surveillance de masse est discuté dans le cadre de la contre-surveillance et des approches de production par les pairs.

mots-clés: fuites d'information, journalisme basé sur la fuite d'information, contre-surveillance, production par les pairs

\section{Öz}

Çalışmanın amacı, ağ temelli bir gazetecilik pratiği olarak bilgi sızıntılarının elde edilmesinden halka ulaştırılmasına kadar uzanan süreç için sızıntı gazeteciliği kavramsallaştırmasını önermek ve kolektif bir üretim biçimi olarak sızıntı gazeteciliğinin kitlesel gözetime karşı sunduğu direniş imkânlarını açıklamaktır. Bu bağlamda öncelikle, Pentagon Dosyalarından Cablegate sızıntılarına kadar dünya siyasetinin akışını değiştiren sızıntıları vakaları, bilgi sızdırma eylemlerinin iktidar yapılarında neden olduğu dönüşümler çerçevesinde tarihsel bir perspektifle ele alınmıştır. Ardından, sızıntı gazeteciliği pratiğinin öncülü olarak görülebilen yurttaş gazeteciliği ve ağ gazeteciliği yaklaşımları açıklanmış ve sızıntı gazeteciliği modeli tarif edilmiştir. Son olarak, sızıntı gazeteciliğinin kitlesel gözetime karşı kolektif bir haber üretim biçimi meydana getirdiği tezi, karşı-gözetim ve müştereklere dayalı kolektif üretim yaklaşımları bağlamında tartışılmıştır.

anahtar kelimeler: bilgi sızıntıları, sızıntı gazeteciliği, karşı-gözetim, kolektif üretim 


\section{Giriş}

Christian Fuchs (2014) asimetrik ekonomik, politik ve kültürel iktidar yapılarının toplumları şekillendirdiği günümüzde, büyük şirketler, hükümetler ve askeri kurumlardan oluşan iktidar elitinin kendisini sıradan yurttaşlardan ve sivil toplum kuruluşlarından ayıran iki özellik barındırdığını belirtir. Birincisi, bu aktörler dünyayı güçlü bir biçimde şekillendirmelerini sağlayan muazzam ekonomik ve/veya politik güce sahiptirler. İkinci olaraksa, faaliyetlerini görünmez kılmaya yarayan kaynakları da ellerinde bulundururlar. Öte yandan, WikiLeaks gibi bilgi sızdırma platformları ve bilgi uçurucular ("whistleblower") ise insanları dışlayan, baskılayan, ezen ve sömüren asimetrik iktidarın gayretine bir karşı-güç oluşturmaya çalışır ve güçlü kurumlar hakkındaki bilgileri kamuya açıklayarak daha simetrik bir iktidar dağılımı için mücadele eder.

"Bir kurumla ilişkili olarak ya da onun kontrolünde gerçekleşen, gerçekleşmiş olduğundan şüphelenilen ya da gerçekleşmesi beklenen ciddi yolsuzluk ya da başka haksızlıklar hakkındaki o kuruma ait bilgilerin, bu bilgilere ayrıcalıklı erişim hakkı olan bir kişi tarafından söz konusu haksızlıkları giderme potansiyeline sahip harici bir kuruluşa ve halka kasten ve gönüllü bir şekilde ifşa edilmesi" (Jubb, 1999) olarak tanımlanan bilgi uçurma ("whistleblowing") eylemi etkisini sadece popüler WikiLeaks vakası ile göstermemiştir. Sahip oldukları mevki ve bilgiyi iktidarları kuvvetlendirmek yerine halkı bilgilendirmek ve kötü amaçlı uygulamaları sonlandırmak için kullanan birçok bilgi uçurucu, yakın tarihin siyasal akışını değiştirecek eylemlerde bulunmuştur. Günümüzde internet ve web'in etkileşimli, katıımcı doğası ise bilgi uçuruculara sızdırdıkları bilgileri halka ulaştırmaları için yeni yol ve yöntemler sunmuştur. Bilgi uçurucular artık internet sayesinde her an her yerden ağa dâhil olabilmekte, profesyonel gazetecilerle birebir ilişkiye sahip olacak kadar yüksek makamlarda olmasalar da edindikleri bilgileri medya kuruluşlarına iletebilmektedirler. Yurttaşlar artık sadece haber yapan amatör gazeteci olmakla kalmayıp, çalıştıkları şirket ya da kamu dairelerindeki yolsuzlukları, kötü uygulamaları webin sağladığı kolaylıklar ve güvenlik imkânları çerçevesinde ilgili kişilere ulaştıran bilgi uçurucuya dönüşmüştür. Bu da bilgi sızıntılarının elde edilmesi ve yayınlanması sürecinin organize yapılar dâhilinde yürütülmesini mümkün kılmıştır.

İktidar yapısına ilişkin kısa bir bakış sunan tek seferlik kısmi ifşaatlar yerine iktidarın nasıl işlediğine, ne düşündüğüne ve ne yaptığına dair sürekli ve kapsamlı görünüm sunan bilgi sızıntıları, araştırmacı gazetecilik anlayışını ve pratiğini de değiştirmiştir. Bir ağ içerisinde elde edilen bilgi sızıntılarının gazeteciler ve uzmanlar tarafından düzenlenerek, anaakım ve/veya alternatif medya kuruluşları aracıı̆ğıla halka ulaştıııması süreci olarak tanımlanabilen "sızıntı gazeteciliği" bugün yurttaş ve profesyonel gazeteci işbirliğiyle hayata geçirilen ve yeni ortaya çıkan katılımcı ve etkileşimli gazeteciliği açıklamak için getirilen yaklaşımlardan biri olan ağ gazeteciliği pratiğinin yenilikçi bir örneği olarak karşımıza çıkar. Muktedirlerin iktidarlarını görünmez kılmak için halktan kitlesel olarak bilgi toplayarak ve onu 
sürekli gözetim altına tutarak tesis ettiği panoptik dünya kurgusuna karşı bir karşıgözetim aracı olarak iktidar ve halk arasındaki asimetrik güç ilişkisini yurttaşlar lehine dengeleyen sızıntı gazeteciliği, ağ üzerindeki mevcut işbirliği olanaklarıyla bilgi sızıntılarının halka ulaştırılması sürecinde kolektif bir üretim biçimi meydana getirir.

Bu çalışmanın amacı, ağ temelli bir gazetecilik pratiği olarak bilgi sızıntılarının elde edilmesinden halka ulaştırılmasına kadar uzanan süreç için "sızıntı gazeteciliği" kavramsallaştırmasını önermek ve kolektif bir üretim biçimi olarak sızıntı gazeteciliğinin kitlesel gözetime karşı sunduğu direniş imkânlarını açıklamaktır. Bu bağlamda öncelikle ABD Savunma Bakanlığı çalışanı Daniel Ellsberg'ün basına sızdırdığı Pentagon Dosyaları, Watergate skandalı ve WikiLeaks'in yayınladığı Cablegate sızıntıları vakaları, bilgi sızdırma eylemlerinin iktidar yapılarında neden olduğu dönüşümler çerçevesinde tarihsel bir perspektifle ele alınacaktır. Ardından, iletişim ortamlarındaki dönüşümün de etkisiyle ortaya çıkan ve sızıntı gazeteciliği pratiğinin öncülü olarak görülebilen yurttaş gazeteciliği ve ağ gazeteciliği yaklaşımları açıklanacak ve sızıntı gazeteciliği modeli tarif edilecektir. Son olaraksa, Foucault'nun toplumu düzene sokmanın rasyonel bir aracı, Marks'ın ise emek ve sermaye arasındaki mücadelenin bir unsuru olarak gördüğü, yeni iletişim ortamlarının sağladığı imkânlarla ise kitleselleşen gözetime karşı sızıntı gazeteciliğinin kolektif bir haber üretim biçimi meydana getirdiği tezi, Christian Fuchs'ın karşı-gözetim ve Yochai Benkler'in müştereklere dayalı kolektif üretim yaklaşımları bağlamında tartışılacaktır.

\section{Pentagon Dosyalarından Cablegate'e, İktidarlara Karşı Bilgi Sızıntıları}

Kimliği belirsiz kaynaklar tarafından kendisine sızdırılan bilgi ve belgeleri halka ifşa eden WikiLeaks adlı kuruluşun tüm dünyadaki 274 konsolosluk, elçilik ve diplomatik misyonu aracılığıyla Amerika Birleşik Devletleri (ABD) Dış İşleri Bakanlığı'na gönderilen gizli yazışmaları 28 Kasım 2010 gecesi yayınlamaya başlaması, Richard Nixon'ı görevinden istifa ederek ayrılan tek ABD başkanı olarak tarihe geçiren "Watergate" skandalına atıfla "Cablegate" adı verilen sızıntıların "diplomasinin 11 Eylül'ü" olarak tanımlanmasını sağlayacak bir etki yaratmıştı. WikiLeaks, aynı yılın temmuz ayında Afganistan, ekim ayında ise Irak savaşına ait yüz binlerce belge yayınlamış, "savaş günlükleri" adı verilen sızıntılar ABD hükümeti yetkililerinin Afganistan ve Irak'ta işlediği savaş suçlarını, tutuklulara uyguladığı işkenceleri ve neden olduğu sivil ölümlerini dünya kamuoyuna ifşa etmişti. Buna karşılık ABD Savunma Bakanlığı Pentagon, gizli belgeleri yayınlayan WikiLeaks'in yaratacağı etkiyle mücadele etmek için özel ekip oluşturmuş, kuruluşun başındaki isim olan Julian Assange hakkında İsveç mahkemelerince "cinsel tecavüz, sarkıntılık ve yasalara aykırı zorlama" suçlamasıyla uluslararası tutuklama kararı çıkarılması girişimleri başlatılmıştı.

Cablegate sızıntılarının kısa süre içinde yayınlanacağı açıklandıktan sonra ise ABD Dış Işleri Bakanlığı bir yandan WikiLeaks ile irtibata geçerek belgelerin 
ifşa edilmesi ile birlikte halkın, insan hakları savunucularının, gazetecilerin, askerlerin, nükleer dengelerin, askeri operasyonların, uluslararası ilişkilerin, ekonomik istikrarın ve ittifakların riske atılacağını bildirmiş ve belgeleri sağlayan devlet görevlilerinin de WikiLeaks çalışanlarının da hukuka aykırı davrandıklarını belirtmişti. Öte yandan bakanlık, açıklanacak belgelerle bozulacağını düşündüğü dış ilişkilerini dengelemek üzere aralarında İngiltere, Avustralya, Kanada, Danimarka, Norveç, İsrail, Rusya, Suudi Arabistan, Finlandiya, Birleşik Arap Emirlikleri, Afganistan ve Türkiye'nin de olacağı ülkelerin hükümet yetkilileri ile görüşmüştü (sol.org.tr, 2010).

Fakat her şeye rağmen, 1966 ila 2010 yıllarını kapsayan 250 binin üzerinde belgeden oluşan "şimdiye değin kamuya açıklanan en yüksek miktardaki gizli belge yığını", WikiLeaks tarafından New York Times, Le Monde, El Pais, The Guardian ve Der Spiegel gazeteleriyle işbirliği içinde yayınlandı. Gazeteler belgelerin haberini birinci sayfalarından verirken, kullanılan manşetler yaşanan siyasal depremin şiddetini açığa vuruyordu. New York Times WikiLeaks belgelerine dair haberini "Leaked Cables Offer Raw Look at U.S. Diplomacy" (Sızdırılan belgeler Amerikan diplomasisine ham bir bakış sağlıyor) manşetiyle verirken, birinci sayfasını tümüyle WikiLeaks belgelerine ayıran The Guardian, "250,000 leaked files that lay bare US views of world" (ABD'nin dünyaya bakışını açığa vuran 250 bin sızdırılmış belge) manşetiyle çıkmıştı. Le Monde "Au cœur de la diplomatie américaine" (Amerikan diplomasisinin kalbinde) derken, Der Spiegel sızıntıları "Enthüllt: Wie Amerika die Welt Sieht" ( $A B D$ ’nin dünyayı nasıl gördügü ortaya çıktı), El Pais ise "La mayor filtración de la historia revela los secretos de la diplomacia de EE UU" (Tarihin en büyük sızıntısı, ABD diplomasisinin sırlarını açığa çıkarıyor) manşeti ile duyurmuştu. Belgeler, hakkında en çok gizli belge açıklanan ikinci ülke olan Türkiye medyasında da yoğun olarak yer aldı. ABD'nin Ankara Büyükelçiliği tarafından hazırlanan raporlarda özellikle dönemin başbakanı ve bakanlarına ilişkin yolsuzluk iddiaları, devlet yöneticileri hakkında ithamlar ve hükümet yetkilileri ve farklı kesimlerden temsilcilerin ABD ile olan ilişkilerini ortaya koyan belgeler haberleştirilenler arasındaydı.

Cablegate sızıntılarının etkisini en güçlü hissettirdiği bölge Kuzey Afrika ve Ortadoğu coğrafyası oldu. 2010 sonunda, Tunus devrimiyle sonuçlanacak halk ayaklanmasına yol açan olaylar için bir katalizör işlevi gören WikiLeaks, Tunus Cumhurbaşkanı Zeynel Abidin Binali'nin ülkeden kaçmasına, siyasal düzenin yeniden tesis edilmesine vesile oldu. Seyyar sebze satıcısı Muhammed Buazizi'nin, daha önceden de tezgâhına defalarca el koyan polisin 17 Aralık 2010'da bir kez daha kendisine müdahale etmesi, arabasına, sebzelerine ve kantarına el koyması üzerine kendisini yakması, halkta biriken öfkenin patlamasına yol açtı. İsyan kısa sürede ülkenin diğer şehirlerine yayıldı. Hükümet, eylemleri polis şiddeti ve katliamlarla susturmaya çalıştı; ama polis şiddeti ters sonuç verdi ve eylemler durmadığı gibi daha da yayıldı. İktidar sembolleri ve Binali'nin yakınlarına ait işyerleri hedef alındı. Protesto eylemleri başkent Tunus'a ulaştığında Binali önce ekmek, şeker ve yağ gibi temel gıdaların fiyatlarının düşeceğini açıkladı, 
ancak eylemler durmadı (Demiralp, 2011). İçişleri Bakanı'nın görevden alınması, Binali'nin cumhurbaşkanlığı seçimlerinde aday olmayacağını açıklaması, daha fazla ifade özgürlüğü söz vermesi, polise gerçek mermi kullanmaması talimatı vermesi ve nihayet hükümeti feshederek seçimlere gidilmesi kararı alması da halkın isyanını durduramadı. Binali ve ailesi değerli eşyalarını da alarak Suudi Arabistan'a kaçmak durumunda kaldı.

Uzun yıllardır ülkenin başındaki baskıcı Binali yönetimine ve işsizlik oranlarını ve gıda fiyatlarını yükselten, yolsuzlukları artıran, ifade ve haber alma özgürlüğünü her geçen gün daha da bastıran ve yirmi üç yıllık iktidarını giderek bir polis devletine dönüştüren uygulamalarına karşı ülke muhalefetinin son zamanlarda zaten protestolarla dile getirmeye başladığı öfkesini patlatan unsurlardan biriyse, WikiLeaks'in isyan henüz başlamadan, 30 Kasım 2010'da yayınlamaya başladığı Tunus Başkonsolosluğu kökenli Cablegate belgeleri oldu. Nawaat.org internet sitesinin "Tunileaks" adıyla Arapça ve Fransızca olarak gerçekleştirdiği yayınlar hükümet tarafından engellense de hızı bir biçimde ülkeye yayıldı. Özellikle Binali'nin ailesi ve eşi Leyla Binali'nin geniş ailesi kastedilerek, ülkeyi bir "aile"nin yönettiği, bu ailenin bir mafya ailesi gibi görülebileceği, Leyla Binali'nin el koyduğu arazilerden birinde devlet yardımıyla inşa ettiği özel okulu Belçikalılara satarak ciddi kazançlar elde ettiği, Cumhurbaşkanı'nın kayınbiraderinin Tunus Bankası başta olmak üzere, finans yönetiminde ağırlığı ele geçirerek türlü dolaplar çevirdiğini belirten belgeler aslında Tunus'ta malumun ilamıydı. Fakat Serhat Ayan'ın ifade ettiği gibi "bir gâvurun aynî ile vaki şeyleri söylemesi bardağı taşırdı" ve isyanın tetikleyici nedenlerinden biri oldu (Uçkan \& Ertem, 2011, s. 115-119).

Tunus'taki isyan daha sonra Mısır'a sıçradı. İşsizlik, yoksulluk ve yolsuzlukları protesto etmek için 30 yıldır iktidarda olan Hüsnü Mübarek'e karşı eylem çağrısına uyarak 25 Ocak 2011'de sokaklara dökülen binlerce Mısırlı, Kahire'nin merkezinden başlayarak iktidar partisinin merkezine, Dışişleri Bakanlığı'na ve devlet televizyonuna yürüdü. Benzer gösteriler ülke çapında diğer şehirlerde de gerçekleşti. Polis göstericilere göz yaşartıcı bomba ve tazyikli su ile saldıııken üç protestocu polis şiddeti nedeniyle hayatını kaybetti. İlerleyen günlerde gösteriler ülke çapına yayıldı, yüzlerce kişi tutuklandı, ancak protestocular taleplerine yanıt verilene kadar gösterilere devam edeceklerini belirtti. Mübarek'in hükümeti feshettiğini ilan etmesine, otuz yıllık iktidarı boyunca ilk kez bir Cumhurbaşkanı Yardımcısı atamasına ve öte yandan ordunun direttiği sokağa çıkma yasağına ve protestoculara ateş açmasına rağmen Kahire'nin merkezindeki Tahrir Meydanı'nda gösterilere devam edildi (aljazeera.com.tr, 2014). Nihayetinde Mübarek, 11 Şubat'ta yetkilerini orduya bırakarak istifasını verdi.

Wikileaks ise bu esnada Mübarek rejimini ve en yakın müttefiki ABD'yi zora sokacak bazı Cablegate belgelerini yayınlamaya başladı. Bunlar arasında Mübarek'in yardımcısı olarak atadığı Mısır İstihbarat Servisi Başkanı Ömer Süleyman'la ilgili olanlar da vardı ve bu belgeler, Süleyman'ın ABD ve İsrail'in adamı olduğunu ifşa ediyor, hatta İsrail ajanı olduğu yolunda bir izlenim bırakıyordu 
(Uçkan \& Ertem, 2011, s. 123). Hamas'a karşı İsrail'in yanında saf tutan ve Gazze'ye uygulanan ablukanın devamından yana olan Süleyman'ın bu tavrı, İsrail karşıtı protestocuların onun cumhurbaşkanı yardımcılığı görevini kabul etmeyerek Mübarek'in istifa etmesi taleplerini sürdürmelerini sağlayan unsurlardan biri oldu.

Tunus ve Mısır'ın ardından hemen bütün Arap coğrafyasına yayılması dolayısıyla tarihe "Arap Baharı" olarak geçen halk isyanları, bilgi sızıntılarının da vesilesiyle zorba devlet başkanlarının iktidarını kaybettiği ilk örnek değildi. 1972 yılının bir gece yarısı, Demokrat Parti'nin Washington'daki Watergate ofis binasına yasadışı izleme ve dinleme gerçekleştirmek üzere sızmaya çalışırken yakalananlar, 37. ABD Başkanı Richard Nixon'ın en yakın yardımcıları tarafından yönetilen bir siyasi istihbarat ve sabotaj operasyonunun elemanları, namı diğer "muslukçular"dı. Kendilerine yapılan ödemeler dahi Nixon'ın yeniden seçilmesi kampanyası için çalışan komitenin örtülü ödeneğinden karşılanmıştı. Demokrat Parti'ye karşı geçekleştirilen bu yasadışı operasyon hakkında başlatılan soruşturma ve bu girişimin suçüstü yakalanması üzerine Beyaz Saray tarafından yürütülen örtbas etme kampanyası, Nixon'ın görevi başındayken kurduğu suç şebekesinin ortaya çıkmasını sağladı.

ABD siyasal tarihinin en büyük "bağırsak temizleme" sürecinde belirleyici olan, Demokrat Parti ofisinde yapılacak istihbarat ve sabotaj operasyonu ile Nixon'ın seçim kampanyası komitesi arasındaki ilişkiyi sorgulayan gazetecilik çalışmaları oldu. Gazetecilerin, çok sayıda anonim kaynaktan aldıkları bilgilerle yaptıkları haberler, gerek Watergate operasyonunda gerekse çok sayıda muhalif odakla ilgili olarak Adalet Bakanlığı, FBI ve CIA'in kullanıldığını, ipin ucunun Beyaz Saray'a kadar uzandığını ortaya koydu. Bu kaynaklar arasında, "Derin Gırtlak" adıyla ünlenecek olan ve çok daha sonra eski FBI Başkan Yardımcısı William Mark Felt Sr. olduğu ortaya çıkan kaynağın gazetecilere sızdırdığı bilgiler, Amerikan derin devletinin birçok sırını ifşa etti (Uçkan \& Ertem, 2011, s. 86).

Watergate skandalı Nixon ve "muslukçular"ın yasadışı operasyonlar için yapmış oldukları ilk mesai değildi. Ekibin kuruluşu, sızdırdığı dosyalar ABD'nin Vietnam işgaline son vermesini hızlandıran Savunma Bakanlığı çalışanı Daniel Ellsberg'e karşı Nixon'ın başlattığı karalama kampanyasına dayanıyordu. Söz konusu dosyalar, ABD Savunma Bakanı Robert McNamara tarafından 1967'de Başkan Lyndon Johnson'ın haberi olmadan kurulan Vietnam Araştırması Görev Gücü ve ABD'nin 1945'ten 1971'e kadar Vietnam Savaşı'na müdahil olmasıyla ilgili yedi bin çok gizli belgeden oluşuyordu. Vietnam Savaşı'nın meşruiyetine ilişkin ülkedeki bakışı tamamen tersine çevirebilecek etkiye sahip belgeler savaşın ABD tarafından çıkarıldığını ortaya koymakla birlikte, Harry Truman'dan Johnson'a dört başkanlık dönemi boyunca yönetimin halktan bilgi sakladığını kanıtlar nitelikteydi. Ellsberg, belgelere erişimi olan ve hükümetle yakın ilişkileri bulunan düşünce kuruluşu RAND Corporation hesabına bu belgeler üzerine çalışmıştı ve Richard Nixon'ın başkanlık seçimlerini kazanmasının ardından beşinci başkanlık döneminde de Vietnam Savaşı'yla ilgili durumun değişmeyeceğini görerek, 
dönemin savaş karşıtı hareketinin de etkisiyle belgeleri basına sızdırmaya karar verdi (Ehrlich \& Goldsmith, 2009).

ABD Hükümeti belgelerin yayınlanmasını durdurmak için çok uğraştı. ABD tarihinde ilk kez, ulusal güvenlik nedeniyle yayın yasaklamaya yönelik bir ihtiyatî tedbir kararı çıkarıldı. Gazetelerin konuyu Yüksek Mahkeme'ye taşımasıyla sonuç ABD Anayasası'nın ifade özgürlüğünü düzenleyen ilk maddesi lehine çıktı ve yasak kaldırılı. Bu olay tarihe, basın özgürlüğü için yapılan mücadelenin zaferi olarak geçti. Yayınlanan belgeler, hükümet dezenformasyonunu açığa çıkaran birçok örnekle ABD karar süreçleri hakkında güvensizlik oluşturdu, savaş karşıtı gösterilerin ve kamuoyu baskısının yoğunlaşmasına katkıda bulundu ve Vietnam Savaşı'nın bitmesinde ciddi bir rol oynadı.

Öteyandan, Ellsberg'ün bireysel çıkışı kendisine yüksek bir bedele mal olarak dışlanmasına, kovuşturulmasına, yargılanmasına, delilikle suçlanmasına, işsiz kalmasına ve tehditler almasına neden oldu. Nixon yönetiminin onunla uğraşmak için kurduğu "muslukçular" ekibi, Ellsberg'ün psikiyatristinden dosyalarını çalıp tahrif ederek onu gözden düşürmeye çalıştı, çantasına uyuşturucu koyup yakalatmayı denedi (Uçkan \& Ertem, 2011, s. 29). Watergate Skandalı'nda da işbaşında olan ekip, iki yıl sonra Nixon'ı istifaya götüren yolun taşlarını döşüyordu. Ellsberg ise "kayda değer bir kişisel riski göze alarak ve yaşamını izinden gitmeleri için başkalarına ilham vermeye adayarak barışı ve hakikati savunduğu için" 2006 yılında Nobel'in alternatifi olarak görülen "Right Livelihood" ödülünü kazandı ve 2013 yılında hükümetlerin kötü yönetim, yolsuzluk ve kanunsuzluklarının ifşa edilmesine odaklı halk yarına gazeteciliği savunan "Basın Özgürlüğü Vakfı"nın kurucularından biri oldu.

\section{Gazeteciliğin Ağ Tabanlı Dönüşümü ve Sızıntı Gazeteciliği}

Ellsberg, bir PDF dosyası olarak yayınlasaydı 10 megabayttan fazla tutmayacak ve bir e-posta eki olarak gönderilebilecek olan Pentagon Dosyaları'nı sızdırdıktan 40 yıl sonra Boston Globe gazetesine vermiş olduğu bir mülakatta, bugün olsaydı dosyaları ne yapacağına ilişkin sorulan soruyu "sadece internete koyardım" diye yanıtlamıştı (McCurdy, 2013, s. 129). Irak'ta istihbarat analisti olarak görev yapan ABD ordusu askeri 22 yaşındaki Chelsea Manning 2010 yılının başlarında öyle yaptı ve "Collateral Murder" adıyla bilinen ve iki Reuters çalışanı ile birlikte Iraklı sivillerin ölümüyle sonuçlanan ABD hava saldırısının görüntülerini, ABD hükümeti yetkililerinin Afganistan ve Irak'ta işlediği savaş suçlarını, tutuklulara uyguladığı işkenceleri ve neden olduğu sivil ölümlerini belgeleyen Afganistan ve Irak savaş günlükleri ile Cablegate belgelerini de içeren 100 binlerce gizli belgeyi internet aracılı̆̆ıla WikiLeaks'e ulaştırdı.

Belgelerin içeriğinin basında ve WikiLeaks web sitesinde yayınlanmasıyla birlikte WikiLeaks'e erişim yasağı uygulanmasının ardından dosyalar ayna siteler ve elektronik basın platformları aracılığıyla halka ulaştıııdı, P2P ağlarına yayıldı, 
sosyal medyada yoğun bir şekilde paylaşıldı (Uçkan \& Ertem, 2011, s. 91). Binali ailesinin yolsuzluklarını anlatan belgelerin Tunus'ta yarattığı infiali hükümet yetkilileri WikiLeaks'i ve belgelerin yayınlandığı diğer internet platformlarının yayınlarına erişimi engelleyerek önlemeye çalıştı. Baskıcı tedbirlere, sansür ve blog yazarlarının, gazetecilerin tutuklanmasına karşı Tunuslular yasakları aşmak için "Tor" gibi anonimleştirici ağ araçlarını kullanmaya ve dağıtmaya başladı. Sonuçta sansür işe yaramadı ve belgelerin okunması neticesinde Başkan Binali'nin yirmi üç yıllık iktidarının etrafında oluşan geniş yolsuzluk çemberinin ortaya çıkması isyanı hızlandırdı.

Tunus devriminin örgütlenmesinde ve iletişim kullanımında internetin önemli bir ağırlığı vardı. Özellikle Twitter ve Facebook gibi sosyal medya platformları, video paylaşım siteleri, P2P ağları, bloglar ve mobil iletişim yoğun bir şekilde kullanıldı. Polisin uyguladığı şiddet ve isyan, cep telefonlarıyla kaydedildi ve YouTube'dan tüm dünyaya yayıldı. Google haritaları üzerinde hükümet binaları, hapishaneler, eylem alanları gibi lokasyonlar işaretlenerek bu haritalar birer iletişim, örgütlenme ve eylem ortamı olarak kullanıldı. Ağ örgütlenmesinin kitlelerin mobilize olmasına ve mesaj yayımına katkısı, aynı ay içerisinde Mısır'da gerçekleştirilen eylemlerde de kendisini gösterdi. Isyanla ilgili gönderileri işaretlemek için Twitter' da kullanılan \#Jan25 etiketi ortak bir sembole dönüşürken, Mısırlı protestocular örgütlenme amacıyla eski ve yeni medya araçlarından faydalandı, yeni medya aktivistleri sosyal medya, bloglar ve video paylaşımlarıyla protestocuları destekledi. İnternetin bilgi paylaşımı için kullanılan ağ yapısındaki rolüyse, Mısır hükümetinin isyanın en hareketli dönemi olan 26 Ocak-2 Şubat tarihleri arasında yurttaşların internete erişimini engelleme kararı almasında en belirgin faktör oldu. Hükümet sadece internetin tamamına erişimi engellemekle kalmadı, cep telefonu iletişimini, sabit telefon hatlarını, bu kanallardan akan her türlü veri ve ses iletişimini kesti. 2 Şubat'ta normal hâline gelene kadar hükümetin denetleyemediği uydu iletişimi dışında Mısır küresel ağda görünmez oldu. Fakat bu önlemler, Mübarek'i iktidarda tutmaya yetmedi. Mısırlılar faks köprüleri, amatör radyo, uydu telefonlarıyla kurulup paylaşılan gayrimerkezi ağlar gibi tekniklerle kesintiyi aştı. Birbirlerine ulaşamayan insanlarsa sokağa çıkmak zorunda kalarak var olan protestocu kalabalığın sayısını birkaç misline çıkardı. Anaakım medyanın görünmez olduğu ya da işlevsiz kaldığı bu baskı alanına yeni iletişim araçları ve kendi ürettikleri alternatif ağlarla giren topluluklar, sivil inisiyatifler, emek örgütleri, hükümet dışı kuruluşlar ve muhalif gruplardan oluşan bu yurttaş medyası, Arap isyanlarıyla birlikte hızlı bir yükselişe sahip oldu. Protestocular haber ve bilgilerin derlenmesi, iletilmesi, analiz edilmesi ve yayılması sürecinde etkin rol oynayarak bilgi akışının yukarıdan kontrol edilmesini engellediler ve yatay olarak birbirlerine bağlandılar; bu da onların hızlı bir şekilde harekete geçebilmelerini sağladı. Sonuç olarak Tunuslu ve Mısırlı protestocular, bugün demokratik gazetecilik, gerilla veya sokak gazeteciliği olarak da anılan ve yurttaşların "haber ve bilgilerin derlenmesi, iletilmesi, analiz edilmesi ve yayılması sürecinde etkin rol oynaması" ile ilişkili olan "yurttaş gazeteciliği"nin en bilinen örneklerinden birini oluşturdu. 
Yurttaş medyası kavramından doğan ve gazeteciliğin ilke ve süreçlerine ilişkin yaşanan değişimi tanımlamak için kullanılan yurttaş gazeteciliğinin kökleri, federalist makalelerin Thomas Paine gibi broşürcü ve anonim yazarlarının kendi yayınlarını bastırarak şöhret kazandıkları 18. yüzyıl ABD’sine kadar uzanır. Bu dönemde telgraf ve telefon ile birlikte posta sistemi gibi diğer gelişmeler de insanların haberleri daha yaygın biçimde dağıtmalarına yardımcı olmuştur (Gillmor, 2004 , s. 2). Modern çağda ise 1963 'te ABD başkanı John F. Kennedy'nin suikast videosu ve 1991 'de Rodney King'in polis tarafından darp edilme görüntüsü olay yerinde yurttaşlar tarafından çekilmiş, 1980'lerin sonunda masaüstü yayıncılığın gelişmesi daha fazla insana kendi yayınlarını tasarlama ve bastırma olanağı sunmuş, 1990'larda web'in ortaya çıkışıyla birlikte ise gerekli araçlara sahip dileyen herkes kendi düşüncelerini dünyayla paylaşmak için bir web sitesi kurabilir hale gelmiştir (Glaser, 2010, p. 579). 2005 yılındaki Londra saldırılarının olay yerinden ilk görüntüleri kendi kameralı cep telefonları ile sıradan yurttaşlar tarafından kaydedilmiş, BBC ve MSNBC gibi anaakım medya kuruluşları bugün birçok büyük yayıncı ve gazetenin de uyguladığı üzere yurttaşlar tarafından üretilen bu fotoğraf, video ve yazılı raporları kabul etmiştir. Yurttaş gazetecileri ve blogger'lar 2004 yılı sonunda Güneydoğu Asya'da yaşanan tsunami ve sel felaketi ile 2005'te ABD'yi vuran Katrina ve Rita kasırgalarının neden olduğu zararlara ilişkin dünya çapında verilen tepkilere ve yardım çalışmalarına da destek olmuş, büyük yıkım nedeniyle anaakım muhabirlerinin ulaşamadığı yerlerden görgü tanığı raporları sunmuştur (Glaser, 2010, p. 580). 1999 yılında Seattle'daki Dünya Ticaret Örgütü toplantısı ve "Seattle İsyanı" olarak bilinen toplantı karşıtı siyasi protestolar hakkında bilgi vermek için kurulan Indymedia web sitesi ise anaakım gazetelerin haber kapsamlarında fark edilen eksikliklere doğrudan ve kararlı bir tepki olarak yurttaş medyasının başka bir örneğini oluşturmuştur (Bruns \& Highfield, 2012).

Shayne Bowman ve Chris Willis (2003) yurttaş gazeteciliğini, haber ve bilgi toplama, bildirme, analiz etme ve yayma süreçlerinde etkin rol oynayan bir ya da bir grup yurttaşın eylemi olarak tanımlar. Haberi kendi izleyicisine tamamlanmış bir ürün halinde dikey bir şekilde sunan geleneksel gazeteciliğin aksine, yurttaş gazeteciliği daima tamamlanmamış ve sürekli gelişmekte olan haberin daha yatay ve etkileşimli bir yolla paylaşılmasını sağlar. İzleyici, editörler ve siyasetçiler gibi muktedirlere sadece dikey olarak bağlı olmamakla kalmaz, aynı zamanda yatay olarak birbirlerine de bağlanırlar; bu da onların harekete geçebilmelerini sağlar (Jurrat, 2011). Bilgiyi meydana getirme ve paylaşmada işbirliğini kolaylaştıran yazılımlar açısından internetin yaşamış olduğu ve "Web 2.0" olarak tanımlanan teknik değişim ise statik içerikten dinamik içeriğe, hiyerarşik olarak yönetilen materyalden işbirliği içinde ve sürekli gelişim halindeki materyale ve tüketici kullanıcıdan katılımcı kullanıcıya olan geçişi temsil eder. Kavramın arkasındaki fikir profesyonel gazetecilik eğitimi olmayan insanların kendi başlarına ya da başkaları ile işbirliği içinde medya oluşturmak, çoğaltmak ve doğrulamak için modern teknolojinin araçlarını ve Internetin küresel dağılımını kullanabiliyor olmalarıdır (Glaser, 2010, p. 578). 
Halkın katııımının gazeteciliği dönüştürmesi ve gazeteciliğin yurttaş ve toplum ile olan ilişkilerinin yeniden tanımlanmasına duyulan intiyaç neticesinde (Beckett, 2010) yeni ortaya çıkan katılımcı ve etkileşimli gazeteciliği açıklamak için getirilen yaklaşımlardan bir diğeri de "ağ gazeteciliği" kavramsallaştırmasıdır (Duffy, 2011). Profesyonellerin ve amatörlerin gerçek hikâyeye ulaşmak için birlikte çalıştı̆̆ı; olguları, soruları, cevapları, fikirleri ve bakış açılarını paylaştığı; haber yapımına ilişkin karmaşık ilişkilerin farkında olunduğu ve üründen çok sürece odaklanılı̆̆ı ağ gazeteciliğinde, gazeteciliğin işbirliğine dayalı doğası göz önünde tutulur (Jarvis, 2006). Bir anlamda, geleneksel habercilik ile cep telefonları, e-postalar, web siteleri, bloglar, mikrobloglar ve sosyal ağlar gibi Web 2.0 teknolojilerinin mümkün kıldığı katıımcı medyanın yeni ortaya çıkan biçimlerinin bir sentezi olarak, halkın kitle kaynak, etkileşim, hiperbağlantı ve kullanıcılar tarafından oluşturulmuş içerikler aracılığıyla gazetecilik üretiminin her aşamasına dâhil olmasını sağlar ve haber yapımını yukarıdan aşağıya doğrusal bir süreç olmaktan çıkararak işbirliğine dayalı hâle getirir (Beckett, 2010).

Ağ gazeteciliğinde web'deki bir habere ilişkin anında bakış açısı sunulması ya da haberin doğruluğu hakkında yorum yapılması, haberi yorumlamak ya da eleştirmek için bağımsız bir araç olarak kullanmak üzere blogların kurulması, Twitter hesapları ya da diğer sosyal ağlar aracılığıyla önemli görülen bilgilere bağlantılar da içerebilen ve medya kuruluşları için önceden sadece kurum içinde ele alınan bir doğrulama hizmeti sunan yorumların yazılması, cep telefonları ile haber değeri taşıyan olayların videoya alınıp YouTube ya da haber sitelerine gönderilmesi, doğal afetler hakkında bilgi derlemek için cep telefonlarından SMS yollanması, kitle kaynak kullanımı tekniği ile binlerce belgenin incelenmesi ve haber değeri taşıyan bilgiyi bulmak için birlikte çalışıması, profesyonel gazeteciler ile izleyicilerin haber üretimindeki işbirliğine dair örnekler arasında sayılabilir (Duffy, 2011). Ağ gazeteciliği böylece anaakım medya kuruluşlarının bağımsız, bireysel ve sosyal medya iletişiminin çok daha geniş ağı ile bağlantı kurmasını sağlamış, birey olarak gazeteci ile haber kuruluşlarının iş yapış biçimini değiştirmiştir (Beckett, 2010).

Bir ağ içerisinde elde edilen bilgi sızıntılarının gazeteciler ve uzmanlar tarafından düzenlenerek, anaakım ve/veya alternatif medya kuruluşları aracılığıyla halka ulaştıııması süreci olarak tanımlanabilen "sızıntı gazeteciliği" ise bugün yurttaş ve profesyonel gazeteci işbirliğiyle hayata geçirilen ağ gazeteciliği pratiğinin yenilikçi bir örneği olarak karşımıza çıkar. Günümüzde bilişim teknolojileri kullanımının dramatik bir şekilde yayılmasının sonucu olarak Cablegate vakasındaki gibi milyonlarca belgenin depolanması için gereken maliyetlerdeki belirgin düşüş ve ağ faktörünün bilgiyi anında çoğaltılabilir ve yayılabilir hâle getirmesi, devletlere ve şirketlere ait sırların saklanmasını oldukça güçleştirmiştir (Lovink, 2010). Pentagon Dosyaları ve Watergate Skandalı vakalarında görüldüğü üzere iktidar yapısına ilişkin kısa bir bakış sunan tek seferlik kısmi ifşaatlar yerine iktidarın nasıl işlediğine, ne düşündüğüne ve ne yaptığına dair sürekli ve kapsamlı görünüm 
sunan bilgi sızıntıları, araştırmacı ve skandal merkezli gazetecilik anlayışını ve pratiğini değiştirmiştir (Beckett \& Ball, 2012).

Beckett'in “maksatlı sızdırma" olarak tarif ettiği (2012) ve Özgür Uçkan'ın (2011; 2012) basın tarihinin başından beri gazeteciliğin asli bir boyutunu oluşturduğunu belirttiği, tarih boyunca demokratik bir işlev yüklendiğini ve vatandaşların "arkalarından çevrilen dolapları" öğrenmelerine yardımcı olan önemli bir iletişim kanalı olageldiğini söylediği sızıntı gazeteciliği, organizasyonel ve operasyonel faktörler ile birlikte sürece dâhil olan aktörlerin eylem motivasyonlarını kapsayan normatif bir model olarak karşımıza çıkar (Çalışkan, 2016). Her bir vakada farklı biçimlerde karşımıza çıkabilse de, bu normların bütünü sızıntı gazeteciliği denilen gazetecilik biçimini açık ve karşıllaştırılabilir biçimde tarif eder.

Sızıntı gazeteciliği modelinin organizasyonel bileşenleri, bilgi sızdırma platformunun ağ temelli ve gayrimerkezi örgütlenme yapısı ile bilgi sızıntısının aktörlerine sunduğu güvenlik ve mahremiyet imkânlarından oluşur. Sızıntı gazeteciliği, sızıntıların gönderildiği internet ortamının karakteristik özellikleri itibarıyla ağ mantığına dayalı, gayrimerkezi, etkileşimli ve kullanıcı denetimli bir mimariye sahiptir. Bilgi uçurucu, sızıntıyı gönderdikten sonra bilgi sızdırma platformunun sunduğu etkileşim olanakları sayesinde sızıntı hakkında, sızıntının alıcısıyla yeniden iletişime geçebilir. Aynı platform aracılığıyla birden fazla bilgi uçurucu sızıntı gönderebildiği gibi, sızıntının birden fazla alıcısı olabilir ve platform üzerinde sızıntı gazeteciliği sürecinin aktörleri işbirliği halinde sızıntı üzerine çalışabilir. Ağdaki herhangi bir aktör sekteye uğratıldığında farklı aktörler ağa bağlanarak ya da aktörler kendini çoğaltarak ağ genişlemeye devam edebilir. Bilgi sızdırma platformunun yöneticisi ise bilgi uçurucu ve alıcılar arasındaki iletişimi mümkün kılacak düzenlemeleri yapar.

Sızıntı gazeteciliğinde bilgi sızdırma platformunun kendisi güvenli bir araç seti olarak tezahür eder. Bu set hem platforma erişimin güvenliğini denetler, hem de platformda saklanan bilgilerin yetkisiz erişimlere karşı güvenli bir şekilde saklanmasını sağlar. Bununla birlikte, bilgi uçurucu ve sızıntının alıcısına, platforma erişirken kimlik bilgilerinin açığa çıkmasını önleyecek güvenlik tedbirleri sunar ve bu tedbirler uygulanmadığı takdirde erişimi engeller. Bilgi uçurucu ve alıcı da ortamın sunduğu güvenlik tedbirlerinin bilincindedir ve ilgili araçları kullanarak bilgileri gönderir ya da bunlara ulaşır. Platform ayrıca bilgi uçurucu ve alıcıyla olan haberleşmenin de anonim bir şekilde gerçekleşmesini sağlayan şifreli güvenlik uygulamaları sunar. Bu uygulamaların başında, mahremiyet koruyucu ve anonimleştirici bir ağ uygulaması olan Tor gelir. Bireysel kullanıcılar web sitelerinin kendilerini ya da aile üyelerini takip etmesini önlemek, haber sitelerine veya anında mesajlaşma servislerine bağlanmak ya da yerel internet sağlayıcıları engel getirdiğinde bu sitelere erişim sağlamak için Tor ağını kullanır. Gazeteciler Tor'u bilgi uçurucular ve muhaliflerle güvenli iletişim kurmak, sivil toplum örgütleri de çalışanlarının yabancı bir ülkedeyken etraflarındakilerin o örgüt için çalıştıklarını 
öğrenmemeleri için kendi web sitelerine bağlanmaları için kullanır (torproject.org). Tails bilgi sızdırma platformları ve gazeteciler tarafından kullanılan, bir DVD, flaş bellek ya da SD kart aracılığıyla herhangi bir bilgisayarda çalıştıılan mahremiyet koruyucu ve anonimleştirici bir işletim sistemidir. Tor2web sistemlerinde Tor yükü olmayan bilgi uçurucularının bilgi uçurma platformuna ve Tor hizmetlerine erişmelerini sağlar. Yaygın olarak kullanılan Secure Sockets Layer (SSL) web şifreleme yöntemi kişisel bilgileri parola peşindeki ağ hafiyelerinden gizlemeye yararken, sızıntı gazeteciliği aktörleri arasındaki yazışmalar PGP ya da GnuPG gibi veri şifreleme ve şifre çözme yazılımları kullanılarak yapılır.

Bilgi uçurucudan medya izleyicisine giden yolda sızıntıların elde edilmesi, gözden geçirilmesi, yayın hazırlanması ve yayınlanması sürecine ilişkin gazetecilik faaliyetleri sızıntı gazeteciliğinin operasyonel bileşenlerini ortaya koyar. Yakın dönemdeki bilgi sızıntılarının ortak yanı, eşi görülmemiş bir kapsama sahip olmalarıdır. Nispeten kısıtlı yetkilere sahip olan fakat genel anlamda devlet sırları hakkında derin endişeler duyan bireyler tarafından gerçekleştirilen bu kitlesel sızıntıları Kwoka "sağanak sızıntı" olarak adlandııı (2015). Sağanak sızıntıların yayınlanmasıyla ilgili ortaya çıkan sorun, yüksek miktardaki verinin derlenmesi, belgelerde adı geçen ve zarar görebilecek kişi ve kurum isimlerinin redakte edilmesi ve bilgilerin bir bağlam içerisinde hikâyeleştirilerek halka ulaştırılmasıdır. Sızıntı gazeteciliğinin operasyonel süreçleri işbirliğine dayalı bu gazetecilik çalışmalarını kapsar.

Yapımcıları aralarında Julian Assange'ın da bulunduğu, İsveçli gazeteci Johannes Wahlström'ün yönettiği Mediastan belgeseli (2013) WikiLeaks'in temel çalışma prensiplerini yansıtır ve sızıntı gazeteciliğinde basınla kurulan ilişkiyi ortaya koyar. WikiLeaks'in Cablegate sızıntılarının yayınlanması için işbirliği yaptığı bir grup gazeteci Orta Asya ülkelerindeki medya kuruluşlarından editör ve gazetecilerle buluşarak, ülkeleriyle ilgili Cablegate belgelerine erişim sunmayı teklif eder. Hangi belgelerin nasıl yayınlanacağını medya kuruluşlarının ve gazetecilerin inisiyatifine bırakılırken, belgelerin yayınlanmasından ötürü zarar görebilecek kişi ve kurumların isimlerinin redakte edilmesi istenir. WikiLeaks tüm bölgesel aktörleri tanıyamayacağından, editörlük çalışmalarının yerel gazeteciler tarafından yürütülmesi gerekir. NSA sızıntılarında ise Edward Snowden elindeki belgeleri sızdırmak amacıyla yönetmen Laura Poitras ile bağlantı kurar; ekibe daha sonra The Guardian'dan Glenn Greenwald ve Ewen MacAskill de katılır. Greenwald ve MacAskill'in görevi muazzam konuları olan, hatta tek bir belgenin bile kendi hikâyesinin olduğu, çok sayıdaki birbirinden alakasız hikâyeyi ortaya çıkarmaktır. Görüşmenin ilerleyen günlerinde Snowden ekibe belgelere nasıl erişebileceklerini ve bunların içeriklerini ve teknik olarak ne anlama geldiklerini anlatırken, ekip de haberleştirdikleri bilgileri kendi gazetelerinde yayınlamaya başlarlar. NSA vakasında, bilgi uçurucunun bağlama ilişkin sadece eksikliğinin değil, tutunduğu tavrın da sızıntıların etkisini değiştireceği gerçeği, sızıntı gazeteciliğinde gazetecinin emeğinin başka bir rolünü ortaya koyar. Snowden, sızıntıları kendi başıma yayınlamak veya halka açmak yerine onları gazetecilere 
verme nedeninin, kendi eğilim, fikir ve sabit görüşlerini denklemden çıkararak halk yararının en güvenilir şekilde temsil edilmesi için sızdırılan bilgilerde neyin halka açık olup, neyin olmayacağı konusunda karar vermek istememesi olduğunu ifade eder (Poitras, 2014).

Son olarak, sürece dâhil aktörlerin motivasyonları sızıntı gazeteciliğinin insan yönünü ortaya koyar. Motivasyon, bilgi uçurma eyleminin ve dolayısıyla sızıntı gazeteciliğinin önemli bir bileşenidir. Bilgi uçurucuyu, bir haksızığın gerçekleştiğine ve bunun düzeltilmesi gerektiğine olan güçlü inancı motive eder ve bu motivasyon, bilgi uçurucuların ortaya çıkarak haksızlığı bildirmelerinde itici güç olur (Roberts, 2014, s. 207). Avustralya'da kamu kuruluşlarında gerçekleştirilen "Whistling While They Work" (Çalışırken Bilgi Uçuranlar) başlıklı araştırma çalışmasının verilerinden hareketle Roberts (2014) söz konusu kurumlarda çalışanların neden bilgi uçurduklarına ilişkin görüşlerini derlemiş, bilgi uçurma motivasyonları için kurum politikaları ile anlaşmazıłk; organizasyonel bağlamda dolandırıcılık, hırsızlık, davranış kurallarının ihlali, ödeneklerin kötüye kullanımı ve kayıtlarda sahtecilik gibi etik ihlalleri; yasal zorunluluk ve kişisel ahlak gibi diğerkâm nedenler tespit etmiştir.

Pentagon Dosyaları örneğinde belgeleri sızdıran kişinin kendisi olduğunu itiraf eden Ellsberg gazetecilere yaptığı açıklamada "Bunu yaparak kendimi tehlikeye attığımın farkındayım ve bu kararımın tüm sonuçlarına katlanmaya hazırım," der. Gazetecilerin "Bu nedenle hapse girme olasıı̆ı̆ı sizi endişelendiriyor mu?" sorusunu ise Ellsberg "Bu [Vietnam'daki] savaşı durdurmak için siz de hapse girmeyi göze almaz mıydını?" diye yanıtlar (Ehrlich \& Goldsmith, 2009). Manning ise casusluktan yargılandığı davanın duruşmasında kendisini "Irak ve Afganistan'daki ABD adına gerçekleştirilen yasadışı eylemleri gördükten sonra dehşete düşerek bunun bir parçası olmayı reddeden ve vicdan azabı çeken bir genç" olarak tanıtır ve Irak'ta ABD'nin saplanıp kaldığı durumun moral bozukluğu ve saplantılı bir şekilde insan kaçırarak ve öldürerek gerçekleştirdiği kontrterör operasyonlarının dehşetiyle, dünyayı daha iyi bir yer hâline getirmek ve ABD dış politikasında ordunun rolüne ilişkin ulusal bir tartışmanın kıvılcımını ateşlemek için, atılan bir dizi yanlış adımın ayrıntılarını içeren muazzam bir gizli askeri tebliğ koleksiyonu olan Irak ve Afganistan savaş günlüklerini sızdırdığını söyler (Reitman, 2013). NSA belgelerini sızdıran Snowden da devlet gözetiminin boyutlarını ve NSA tarafından yönlendirilen insansız hava araçlarının saldııırını görmesinin kendisini harekete geçmeye teşvik ettiğini söyler (Poitras, 2014). ABD'de devlet gözetimine karşı bireysel özgürlükler için başkaldırarak bilgi sızdırmanın hukuki sonuçları hapse girmek ve bireysel özgürlüklerin tamamen kaybolması anlamına gelebilmektedir. Gazeteci Greenwald'ın bu yöndeki "Böyle bir sıkıntıya gitmeye değer olduğu sonucuna nasıl vardın?" sorusunu ise Snowden "Çevremde, kendim kadar değer verdiğim insanların zarar görmesindense hapse girme riskini almaya ya da kişisel olarak herhangi bir negatif sonuca katlanmaya hazırım." diyerek yanıtlar (Poitras, 2014). 
Bilgi uçurucuların gösterdiği bu tutum, sızıntı gazeteciliğinin organizasyonel ve operasyonel bileşenlerinin yanında ve bu bileşenlerin hayata geçmesini sağlayan üçüncü unsurdur. Halkın yararına işbirliği yapma amacıyla gösterilen diğerkâm davranış bilgi uçurucunun sahip olması gereken bir karakterdir ve ancak bu karaktere sahip kaynakların harekete geçmesiyle sızıntı gazeteciliğinde bilgi akışı gerçekleşmeye başlar.

\section{Kitlesel Gözetime Karşı Kolektif Üretim}

İktidar ve halk arasındaki asimetrik güç ilişkisini yurttaşlar lehine dengelemesi bağlamında sızıntı gazeteciliği deneyiminin ortaya çıkardığı iki temel sonuç vardır. Bunlardan ilki, bilgi sızıntılarının muktedirlerin iktidarlarını görünmez kılmak için halktan kitlesel olarak bilgi toplayarak ve onu sürekli gözetim altına tutarak tesis ettiği panoptik dünya kurgusuna karşı bir karşı-gözetim aracı, bilgi uçurucuların mahremiyetinin ise muktedirlerin baskısına karşı kendilerini korumak için kullandıkları bir öz savunma mekanizması olduğudur.

Foucault'nun "toplumu düzene sokmanın rasyonel bir aracı" olarak tarif ettiği gözetim moderniteye içkin bir kavramdır ve kapitalist sistem içinde fabrika ve atölyelerde işçilerin sermaye adına disipline edilmeleri yoluyla görülür (Dolgun, 2008, s. 77). Marx bu bağlamda gözetimi, emek ve sermaye arasındaki mücadelenin bir unsuru olarak görür. İşçileri fabrikalarda ve atölyelerde bir araya getirme fikri sık sık, teknik verimliliği azamiye çıkarmanın, makinelerin tam kullanımını sağlamanın bir yolu olarak görülse de Marx'a göre işçilerin faaliyetlerinin gözetimi yoluyla emeğin disiplininin sağlanması, en az ötekiler kadar önemlidir (Lyon, 1994, s. 25). Fabrika dışında ise Foucault gözetimin modern sosyal kurumların kullandığı, hayatın düzenlenmiş ve belirlenmiş bir yolda sürmesini garanti eden disipline edici uygulamalar dizisi olduğunu söyler (Dolgun, 2008, s. 105).

Yeni siyasal, ekonomik ve iletişimsel düzenin motor gücü olan yeni iletişim ortamlarının günümüzde sağladığı gözetim imkânları ise üç alan altında tarif edilebilir (Çalışkan, 2010). Birincisi, kapitalist toplumda çalışanların iş verimliliğinin sağlanması ve kişisel yaşamlarının gözetlenmesi; ikincisi, yurttaşların potansiyel birer müşteri olarak kapitalist işletmeler tarafından pazarlama ve satış açısından tüm satın alma ve satın alma ilişkili aktivitelerinin gözetlenmesi; son olarak yine yurttaşların devletler ve daha üst bir şemsiye olarak IMF, Dünya Bankası, NATO, $A B$ gibi ulusötesi kurumlar tarafından kapitalist sisteme ve onun konjonktürel koşullarına ayak uydurması amacıyla gözetlenmesi.

Emek ve sermayenin arasındaki mücadelenin bir unsuru olarak yeni iletişim ortamlarındaki gözetim uygulamaları, kapitalist üretim biçimlerindeki değişim ve postfordist üretime geçişte yaşanan dönüşümler paralelinde ele alınır. Fordizm, yalnızca bir fabrika üretim biçimi değil aynı zamanda modernizmin toplumsal yapıtaşlarını da oluşturan sosyal ve siyasal bir düzenlemeye işaret eder. Fordizmin 
standart ve seri üretime dayalı ekonomik örgütlenmesi aile, boş zaman ve gündelik yaşamın her alanını kapitalist toplumsal ilişkiler çerçevesinde düzenleyen bir işleve sahiptir. Bu bir yaşam biçimi olarak kitle üretimi ve tüketiminin yaygınlaşmasıyla kendisini ifade eder. Fordizmin yalnızca bir ekonomik örgütlenmeyi değil, bütün bir kültürü nitelemesi gibi postfordizm de çok daha geniş ve derin toplumsal ve kültürel gelişmelerin adıdır. Postfordizm standartlaşmış ürünleri, sermaye yoğunlaşmasını, seri üretim döneminden farklı, bütünüyle yeni bir devri anlatan bir terimdir. Özünde, 1960'lı yıllardan itibaren dünya kapitalist sermaye birikiminde yaşanan krizi aşmanın bir yolu olarak, ekonomik yeniden yapılanmayı tanımlar. Bu yeniden yapılanma, teknolojinin, emeğin işbölümünün örgütlenme yapılarının esnekleşmesi ile nitelenen bir süreçtir ve özelleştirme gibi devletin küçültülmesi politikaları ile birlikte gelişir. Postfordist yaklaşıma göre, yeni zamanların merkezi sanayileri, enformasyon teknolojileri ve mikro elektroniğe dayalı üretimdir. Yeni teknolojiler daha yoğun bir otomasyona olanak tanır ve üretimin, esnek, otomatik ve derli toplu olmasını sağlar (Timisi, 2003, s. 103-104).

Lyon (1994, s. 129-130) 1990'larla birlikte iş yerindeki elektronik gözetimin daha yaygın ve yoğun hale geldiğini ve hatta iş yeriyle sınırlı kalmamaya başladığını belirtir. Evlerinde klavyeleri başındaki veri girişi çalışanlarının ve şirketlerinin bulunduğu ülke dışındaki çalışanların aktivitelerin dâhi izlenmesi mümkün olmuştur. Uzun yol kamyon sürücülerinin ne kadar frene bastıkları, ne kadar hızlı gittikleri işverenleri tarafından takometreler aracılığıyla bilinebilmektedir. Işse girdikten sonra çalışanların iş yerlerine ve işyerlerindeki bazı bölmelere girebilmek için plastik kartlar ve bazı durumlarda biyometrik güvenlik sistemleri ve elektronik olarak saklanan parmak izleri, retinal örüntüler veya ses testleri kullanmaya başlamıştır. Bu teknikler, geçmişte turlarını tamamladıklarını kanıtlamak ve hırsızlık durumunda şirketlerinin o anda nerede bulunduklarını saptayabilmesini sağlamak için gece bekçilerinin kullandıkları anahtarlı saatler üzerine geliştirilmiştir. Barkodlama teknikleri, işverenlerin ücret ödemeleri ve verimliliğin ölçülebilmesi için çalışma günlerini dakika-dakika tahsis edilebilen çalışma saatlerine bölebilmelerini sağlamıştır. Şifreli güvenlik kilitleri iş yeri ve ofislerin belirli bölmelerine giriş kısıtlamaları için kullanılmıştır. Bu ve benzeri aygıtlar işin zamanlamasının ve konumlamasının takip edilmesine ve manipüle edilmesine yardım etmiştir. Herhangi bir zamanda işçilerin nerede bulunduklarının yönetime bildirilmesine yaramıştır. Bununla birlikte, yapılan işin gidişatı ve kalitesi de elektronik izlemeye konu olabilir. Tuş vuruşu hesabı böyle bir otomatik gözetime örnek gösterilebilir. Yine veri güvenliği sistemleri, satış denetimleri, telefon operatörleri ve telefon konuşmaları ile diğer tüm iletişimlerin kontrolü bu tür gözetim tekniklerine örnek teşkil eder. Dolayısıyla postfordist dönemde gözetim, üretim aktivitelerinin mevkilerine el atmakla kalmamış, tüm ofisler ve restoran ve taksi şirketleri gibi alanlara da uzanmıştır.

Yeni iletişim ortamlarının sahip olduğu muazzam teknik kaynaklar, gelişmiş toplumlardaki hane halkı bireylerinin tüketim aktivitelerini yönlendirmeleri için de geniş bir alan sağlar. Satın alma örüntüleri ve satın alma gücü kayıtlarından elde 
edilen veriler, tüketicileri sonraki harcamaları için etkilemek ve önceki tüketim deneyimlerinde ilgili tüketim standartlarına uymadığı hakkında kaydı bulunanlara veya harcama izinlerinin dışına çıkarak kabul edilemez borçların ortaya çıkmasına neden olanlara engel olmak için kullanılır. İstenmeyen ("junk", "spam") postalar, tüketici gözetimi tekniklerinin özüne sahip yöntemlerden biridir. Mal ve hizmet satma amacındaki çoğu şirket, olabildiğince kesin bir şekilde potansiyel müşterileri hedefleyen elektronik araçlara sahiptirler. Nerede ve kiminle yaşadığımızı, nasıl kazanıp nasıl harcadığımızı bilirler. İstenmeyen postalar, gelişmiş toplumların "tüketim kapitalizmi" çağında yaşadıklarının bir kanıtıdır. Ancak bu tüketim özgürlüğü dünyası, aslında bir sosyal denetim dünyasıdır. Özetle, Lyon'a göre (1994, s. 136-138) tüketim gözetimi kapitalist işletme stratejilerinin açıkça bir bölümünü oluşturur. Gözetim, elektronik bilişim hizmetleri ve işlemleri aracılığıyla gitgide daha çok ve daha derinden ticari alana yayılır ve bu durum mahremiyet için tehdit oluşturan sonuçlara yol açar.

Snowden'ın ABD Ulusal Güvenlik Ajansı (NSA) ile ilgili belgeleri basına sızdırması ise devletlerin yurttaşların kapitalist sistem tarafından denetlenmesine yönelik kitlesel gözetim uygulamalarının çarpıcı bir örneğini oluşturur. Belgelere göre NSA, Verizon telekom şirketinin bütün abonelerinin elektronik bilgilerini ve yaptıkları tüm yurtiçi ve uluslararası aramaları izlemiş, Prizma adı verilen bir program çerçevesinde aralarında Google, Facebook ve Apple'ın da bulunduğu dokuz internet şirketinin veri tabanlarına girmiş, internet üzerinden gönderilen tüm e-postalara, yapılan sohbetlere, internet telefonu aracılığıyla yapılan görüşmelere, görüşmeyi yapan kişilerin isimlerine, bulundukları yere ve diğer ayrıntılara ulaşmış, ABD'de yaşayan tüm yabancıların telefon konuşmalarını ve elektronik postayla iletişimlerini takip etmiş, Amerikalı olmadıkları düşünülen ama daha sonra yapılan incelemelerde Amerikan vatandaşı oldukları ortaya çıkan bireyler hakkında da bilgi toplamıştır. ABD'nin uyguladığı gözetim ülke sınırlarıyla sınırlı kalmamış, kendi Avrupalı müttefikleri, AB konsoloslukları, hedef olarak seçilen $A B$ parlamenterleri ve Türkiye'nin de aralarında olduğu birçok ülkeden resmi yetkililer gözetlenmiş ve yasadışı olarak dinlenmiştir. Bu amaç doğrultusunda kullanılan yöntemler arasında veri toplamak için elektronik cihazlara yerleştirilen böcekler ve hedeflenmiş bilgisayarlardaki her türlü verinin kopyasını çıkaran yazılımlar bulunur.

Yeni iletişim ortamları öte yandan, yurttaşların muktedirleri gözetlemesi ve mazlumlara karşı haksız uygulamalarına halkın dikkatini çekmek için karşı-güç kullanmasına yönelik bir potansiyel de barındırır. Bu yüzden ağlar bir gözetim gücü olduğu kadar bir karşı-gözetim gücüdür de ve izleyenlerin izlenmesi, gözetleyenlerin gözetlenmesi için imkân sunar. Snowden ironik bir şekilde dünyanın belki de en kapsamlı gözetleme aygıtının iç yüzünü tartışmaya yer bırakmaksızın ifşa ederek, yeni iletişim ortamlarının sadece devletlerin ve şirketlerin yurttaşları izlemelerini ve haklarında siyasal ve kriminal profiller oluşturmalarını sağlayan bir gözetim aracı olmadığını göstermiştir. Chelsea Manning ve WikiLeaks, Afganistan ve Irak'ı kana bulayan, savaş suçları işleyen, 
tutuklulara işkence uygulayan ve sivil ölümlerine neden olan ABD komplosunu açığa çıkarmak için yeni iletişim ortamlarını, interneti, P2P ağlarını kullanmıştır.

Dolayısıyla sızıntı gazeteciliği muktedir sınıflara karşı mücadele etmek ve iktidarı şeffaflaştırmak için bilgi yayınlayarak, asimetrik ekonomik ve siyasal iktidar ilişkilerine karşı direnenlerin girişimi olarak görülebilir. İnternet üzerinde faaliyet gösteren bilgi sızdırma platformları, devasa mali güce ve etkiye sahip olan, böylece kendi operasyonlarının detaylarını, boyutlarını, mahiyetini ve sonuçlarını çoğunlukla gizleyebilme imkânını elinde bulunduran büyük şirketlerin ekonomik ve siyasal iktidarlarını, uyguladıkları baskı ve haksızlıkları görünür kılmışlardır. Internetin birçok kişinin hayatını şekillendirdiği, bilgi, iletişim ve kolektif üretim için yeni bir kilit ortam hâline geldiği, iktidarın panoptik gözünü genişlettiği, fakat aynı zamanda normalde gözetimin objesi olanların gözlerini, kulaklarını ve seslerini muktedirlere yöneltmesini ve gözetimin gücünü tersine çevirmesini sağladığı günümüzde, birer karşı-gözetim unsuru olarak WikiLeaks ve diğer bilgi sızdırma platformları muktedir organizasyonlar hakkındaki bilgileri halka açması ve onları şeffaflaştırması; öte yandan, yurttaşların, işçilerin ve tüketicilerin baskı altında tutulmasına karşı tahakküm altındakiler adına gerçekleştirilen bir öz savunma tepkisidir. Bu öz savunmanın araçları ise Tor, Tails, PGP gibi mahremiyet güvencesi sağlayan uygulamalardır.

Fuchs, ABD gibi süper devletler ve NSA gibi kurumların mazlum halkların üzerine gözlerini dikmek için kullandıkları gözetim ile bilgi sızıntısı platformlarının karşı-gözetim yoluyla muktedirleri şeffaflaştırma girişimleri arasında ise fark gözetir (Fuchs, 2014). İlki, halkı kontrol etmek ve daha da çok baskı altında tutmak içindir; ikincisi ise mazlumların ya da mazlumlar adına hareket edenlerin baskıya karşı kendilerini korumak için kullandıkları bir savunma mekanizması ve bir mücadele biçimidir. Gözetim otoritenin, şeffaflık ise demokrasinin işlerliğinden, muktedirlerin sorumlu tutulmasından yanadır. Ekonomik ve siyasal iktidar hakkında gizli belgeler sızdırarak iktidarı şeffaflaştırmayı amaçlayan bir proje olarak WikiLeaks, muktedirler hakkında bilgi toplanması sürecine kendisi dâhil değildir ancak kurumların usulsüz uygulamalarına tanıklık eden ve neler olup bittiği hakkında daha fazla şeffafılık sağlamak isteyen içeriden kişiler, bilgi uçurucular tarafından internet aracılığıyla gerçekleştirilen anonim gönderimlere dayanır ve odak noktası belirli bir dereceye kadar ekonomik ve siyasal şeffafılıktır.

Pieterse'ın şeffaflık kavramsallaştırmasına ilişkin yapmış olduğu hegemonik ve radikal ayrımları, karşı-gözetim gücü olarak bilgi sızıntılarının işlevinin daha iyi anlaşılmasına yardımcı olur. Pieterse'a göre (2012) hegemonik şeffaflık, yukarıdan aşağıya doğru şeffaflık demektir ve "diğerleri" için şeffaflık sunar. Bu, otoriter bir düzende ya da George Orwell'in 1984 romanında olduğu gibi panoptik bir dünya anlamına gelir. Totaliter rejimler, istihbari izleme yoluyla aydınlatılmış, kendileri için opak hale gelmiş, şeffaf ve açık bir toplum kurgusu peşindedirler. Şirketler ve bankalar pazarlama, yönetim riski ve toplumsal tasnif amaçları doğrultusunda tüketiciler ve kredi davranışları hakkında kişisel bilgi toplar. Bu gözetim teknikleri 
indirgemeci, denetim odaklı, gayri demokratik ve tek yönlüdür; bağıntısal değildir ve karşılıksızdır. Peşinen çalışır ve sosyal kategorizasyona yol açarak dijital ayrımcılık yaratır. Tek yönlü şeffaflığın kuralları uluslararası kurumlar için de geçerlidir. IMF ve Dünya Bankası mali destek arayışında olan devletlerden kayıtlarını açmasını talep eder ama kendileri kayıtlarını açmaz ve hangi program ve projelerin hangi nedenlerle fonlandığını ifşa etmez. Bir kıstas ve yardım koşulu olarak Batılı kurumlar tarafından 1990'lardan bu yana desteklenen "iyi yönetişim" de benzer bir anlam barındırır. Öyle ki, ABD, diğer Batılı ülkeler ve uluslararası kuruluşlardaki yönetim ve insan hakları uygulamalarının sorgulanması söz konusu değildir. Denizaşırı ülkelerde uygulanması önerilen "eş-dost kapitalizmi" dir. Çifte söylem ve çifte standartlar, hegemonik şeffaflığın yerleşik özellikleri arasındadır.

Bilgi sızdırma platformları hegemonik şeffafık üzerindeki örtüyü kaldırarak, radikal şeffaflığı ortaya çıkarır. Bu bağlamda radikal şeffaflık Uçkan ve Ertem'in ifade ettiği üzere $(2011$, s. 55) "herkes için daha iyi ve daha adil bir topluma yol açacağı, daha ince eleyip sık dokuyan araştırmacılığın hükümet, şirketler ve diğer organizasyonlar da dâhil olmak üzere toplumun tüm kurumlarında yolsuzluğu azaltacağı ve demokrasiyi güçlendireceği, sağlıklı, canlı ve sorgulayıcı bir medyanın bu amaçlara ulaşmak için vazgeçilmez olduğu" iyimser fikrine dayanır. Burada özellikle WikiLeaks'in şeffaflığa ilişkin yaklaşımı için anahtar olarak gördüğü diğer iki kavram ise "açık hükümet" ve "açık yönetişim" kavramlarıdır. "Biz hükümetleri açarız" sloganı ile yola çıkan WikiLeaks, hedeflerinden biri arasında iyi yönetişimin desteklenmesi olduğundan bahseder (wikileaks.ch, 2010): "Açık hükümet haksızlığa neden olmak yerine, buna karşıık verir. Açık hükümet yolsuzluğu açığa çıkartır ve çözer. Açık yönetişim, iyi yönetişimi teşvik etmenin en etkin yöntemidir".

İyi yönetişim ise Uluslararası Para Fonu'nun (IMF) borçlu ve yoksul ülkelerin IMF kredisi almak için yerine getirmek zorunda oldukları koşulları tanımlamak için kullandığı bir kavramdır. Bu koşullar bir yandan borçlu ülkelerin yolsuzlukla mücadeleye, öte yandan, "kamu sektörü kurumlarını kapsayan reformlar yoluyla kamu kaynaklarının yönetiminin iyileştirilmesine" ve "özel sektör faaliyetlerinin verimli bir şekilde yürütülmesine olanak sağlayacak şekilde şeffaf ve istikrarlı bir ekonomik ve düzenleyici ortamın gelişimi ve sürdürülmesinin desteklenmesine" yönelik sorumluluklarını içerir. Bu anlamda Fuchs (2014) iyi yönetişim kavramının kuralsızlaştırma, kamu sektörünün serbestleştirilmesi ve özelleştirmesi, yoksul ülkelerde eğitime, refaha, sosyal güvenliğe ve sağlığa yönelik devlet bütçelerinin kesintiye uğratılması ve Batılı şirketler için yoksul ülkelerde yaratılan servetin ve kazancın Batı'ya aktarılmasını sağlayan yatııım fırsatlarının açımasına yönelik uluslararası neoliberal politikaların bir ifadesi olduğunu söyler. WikiLeaks'in belli bir dereceye kadar şirket iktidarlarının olumsuz etkileri konusunda endişesi olduğunu gerçeği göz önüne alındığında ise, kendini tanımlarken neoliberal bir ifade olan iyi yönetişimi kullanması şaşırtıcıdır ve organizasyonun kendisiyle çelişir. Cablegate sızıntısı sonrasında WikiLeaks'in ekonomik gelirlerinin önüne geçen banka blokajları ve yayınını engelleyen hizmet sağlayıcılarının yasakları göz 
önüne alındığında, bilgi sızdırma platformlarının devlet iktidarına karşı şirketlerin iktidarını hafife almaması gerektiğini ortaya koyar.

Bu aynı zamanda WikiLeaks'in idealize ettiği ifade ve haber alma özgürlüğü gibi liberal değerlerin korunması için de önemlidir. İfade ve haberleşme araçlarının büyük bir bölümünü özel olarak kontrol ederek düşünce ve ifade özgürlüğü üzerinde hâkimiyet kurma eğilimindeki şirketlere ayrıcalık tanıyan, kapitalist sistemin kendisidir ve bu nedenle modern toplumlarda bu özgürlükler hiçbir zaman tam anlamıyla gerçekleşmemiştir. Fuchs bu bağlamda Habermas'ı hatırlatarak, liberal kamusal alanın, kapitalizmde yurttaşlar kamusal alana dahil olmak için eşit formel eğitime ve maddi kaynaklara sahip olmadığından ötürü kendi düşünce ve ifade özgürlüğü değerlerini, büyük siyasal ve ekonomik organizasyonlar etkin bir şekilde siyasal örgütlenme ve toplanma hakkını kendi tekellerine almanın keyfini sürdüklerinden ötürü ise kendi örgütlenme ve toplanma özgürlügünü sınırladığını söyler. WikiLeaks'in eleştirdiği iktidarların gayri şeffaf yapısı liberal değerlerin dışında değildir ve liberal-kapitalist rejimlerin ayrımaz bir parçasıdır. Şirketlerin iktidarı ve bu iktidarın kapitalist devlet tarafından desteklenmesi, kapitalist düzenin korunması ve genişletilmesi amacıyla gizli tutulur ve gizlilik ve özel mülkiyet gibi liberal değerlerle meşrulaştırııı. Şirket hegemonyası ve devlet hegemonyası ise modern toplumlarda ayrı değil, birbirine bağlı kavramlardır. Çağdaş devletler özel mülkiyeti koruyarak, neoliberal politikalar uygulayarak ve yeni bir küresel emperyalist düzeni tesis etmek amaçlı savaşlar çıkararak şirket kurallarını uygularlar. Liberal düşüncenin etkisindeki WikiLeaks liberal değerleri savunur ve bu nedenle kendi sorguladığı olayları temel nedeninin liberal-kapitalist düzen olduğunu göz ardı eder.

Bir diğer yandan, bilgi sızıntılarının iktidarı içine soktuğu krizlerin ve karşı-gözetim aracılığıyla şeffaflaşmasının otomatik olarak siyasal ve ekonomik dönüşümlere neden olacağı düşüncesi de bir yanılgıdır. Pentagon Dosyaları $A B D$ hükümetlerinin savaş politikalarını ifşa etmiş ve Vietnam işgalinin sona erdirilmesine katkı sunmuş olsa da ABD'nin emperyalist yayılmacılığını, Afganistan ve Irak işgallerini önleyememiştir. WikiLeaks'in ABD'nin Afganistan ve Irak'ta işlediği savaş suçlarını halka teşhir etmesi neticesinde ABD doğrudan askeri işgaller yoluyla yayılma politikalarını gözden geçirmiş olsa da, Ortadoğu ve Afrika ülkelerinde vekilleri aracılığıyla savaşlarını yürütmeye devam etmiştir. NSA sızıntılarıyla siyasal iktidarın sahip olduğu gözetim imkânlarının bilinir olması ise yurttaşların kimliklerini gizleyici ve gözetimi önleyici öz savunma araçlarını kullanmayı öğrenmesine vesile olmuştur. Siyasal ve ekonomik iktidarın hegemonyası, en derin yaraları aldığı anlarda dahi saldırılara yanıt verebilmiş ve hegemonyasını yeniden tesis etmeyi başarmıştır.

Christine Buci-Glucksmann bu durumu Gramsci'nin gelişmiş kapitalist ülkelerin Batılı toplumlarına özgü "devlet aygıtlarının dayanıklı̆ğı" analizi ile açıklar. Bu dayanıklılık öyle güçlüdür ki, hâkim sınıfların kriz dönemlerindeki 
organizasyonel rezervlerinin tahmin edilenden her zaman daha güçlü olduğu bu tür toplumlarda hegemonyanın yıkılması için Gramsci'yi yeni bir yol göstermeye zorlamıştır (Buci-Glucksmann, 1980; Aktaran: Tietze, 2010). Bu da karşıhegemonik hareketlerin - ki bilgi sızıntıları bu kapsamda değerlendirilebilir geliştirilmesinin yanı sıra yeni ve çok farklı bir hegemonya formunun oluşturulması gerekliliğidir. Bu form, WikiLeaks'in iyi yönetişim gayesine benzer bir şekilde var olan hegemonik ilişkilerin üstesinden gelmeli, ancak onun da ötesine geçerek güvenlik ve mahremiyet araçlarının sistematik olarak kullanılmasına artık gerek duyulmayacak şekilde toplumu demokratikleştirmelidir.

İkinci sonuç ise bilgi sızıntılarının sızıntı gazeteciliğiyle halka ulaştıııması sürecindeki gazetecilik çalışmalarının, ağ üzerinde mevcut işbirliği olanaklarıyla kolektif bir üretim biçimini meydana getirdiğidir. Halkın katılımının gazeteciliği dönüştürmesi neticesinde yeni ortaya çıkan katılımcı, etkileşimli, haber sürecinin ağ temelinde işlediği ve haberle sürekli bir iletişimin ve etkileşimin söz konusu olduğu ağ gazeteciliği, gazeteciliğin işbirliğine dayalı doğasını göz önünde tutar. Profesyonel gazeteciler ve yurttaşlar gerçek hikâyeye ulaşmak birlikte çalışır; olguları, soruları, cevapları, fikirleri ve bakış açılarını paylaşır. Halk bir habere daha yayınlanmadan dâhil olabilir, olgu, soru ve önerilerle katkı sunabilir (Jarvis, 2006). Gazeteciler haber yapımında halkın desteğine güven duyabilir ve aynı habere ilişkin diğer çalışmalara, kaynak materyale ve hatta kaynakların blog gönderilerine bağlantı sunabilir. Haber çevrimiçi, basılı ya da başka herhangi bir şekilde yayınlandıktan sonra halk tashih, soru ve bakış açılarıyla katkı sunmaya devam edebilir. Bu işbirliğini mümkün kılan unsurlardan biri ise cep telefonları, e-postalar, web siteleri, bloglar, mikrobloglar ve sosyal ağlar gibi Web 2.0 teknolojilerinin sunduğu katılım ve etkileşim imkanlarıdır.

Ağ gazeteciliği pratiğinin yenilikçi bir örneği olarak sızıntı gazeteciliğinin işbirliğine dayalı bu çalışma mantığı, yıllardır iktisatçılar, politikacılar ve yasa yapıcılar, iş idarecileri ve mühendisler toplumsal, kurumsal ya da kamusal hedeflere ulaşmak için bütün sistem ve organizasyonların teşvik, ödül ve ceza üzerine kurulması gerektiğini varsayımı ile ters düşer. Bu varsayımın dayandığı tez Benkler'e göre (2012, s. 10-12) insanların temelde kendi çıkarlarının güdümünde hareket eden bencil yaratıklar olduğu ve başkalarının iyi davranması isteniyorsa onların gözlemlenmesi, ödüllendirilmesi ve cezalandıııması gerektiği varsayımıdır. Thomas Hobbes'in (1993) insanların temelde ve evrensel olarak bencil olduğu ve onlarla başa çıkabilmenin tek yolunun devletlerin devreye girerek basiretsiz kişisel çıkar arayışında birbirlerini yok etmesini ya da başkalarının yaşamını dayanılmaz hale getirmesini engellemek için insanları kontrol etmesine dayandığı "Leviathan" yaklaşımı ve insanların doğaları gereği çıkarcı olduğu, maliyet ve yararların akılcı bir değerlendirmesi temelinde karar verdikleri için, serbest piyasadaki eylemlerinin toplumun iyiliğine hizmet etme eğiliminde olacağını öne süren Adam Smith'in (2010) bencilliğe karşı koymak için önerdiği "görünmez el" çözümü, insanlığın bencil olduğu inancını temel başlangıç noktası alır. Leviathan 
bencil insan davranışını denetleme ve cezalandırma yoluyla dizginleyip kontrol altına almaya çalışırken, "görünmez el" kişisel çıkarlarının insanları toplumun iyiliğine hizmet edecek davranışlara yönelteceği pazarlar hayal eder.

Yirminci yüzyllın büyük bir bölümünde tercih edilen yaklaşımlar Leviathan'ın yansımalarıyken ve sistemlerin çoğu büyük, hiyerarşik ve kontrole dayalıyken, son birkaç on yıldaki bir dizi değişiklik, bu evrensel bencillik teorisinden temel bir uzaklaşmayı tetiklemiştir. Resmiyetten görece uzaklık ve toplumsal katılımın yanı sıra özerklik ve yaratıcılığa öncelik tanımasıyla yeni teknolojik şirket ve kuruluşlar, internette serbest ve açık kaynak yazılımlardan Wikipedia gibi katıımcı uygulamalara, yurttaş gazeteciliği uygulamalarından sosyal ağlara kadar eşit koşullarda kolektif üretimin yükselişe geçmesi, doğru koşullar sağlandığında, insanların organizasyonların kolektif çıkarına hizmet etmek için kendi özgür iradeleriyle iş birliğini ve birlikte çalışmayı tercih ettiğini göstermiştir. Üstelik birbiriyle sosyal etkileşim içinde birlikte çalışma ilişkisi yaratıldığında bireylerin üretken sonuçlar elde etmeye motive edilebileceğini öne süren daha iyimser, insancıl ve insanlığa yakışır bir görüşe doğru bu kayış iş dünyasının ve internet ortamının çok ötesine uzanmış, bu ortamlardaki kolektif çabaların başarısı çok çeşitli sosyal sistemlere de yansımıştır. Belki de insanoğlunun doğası gereği o kadar bencil olmadığı şüphesiyle yüzlerce bilim insanının yapmış olduğu çalışmalar sonucunda psikoloji, örgüt sosyolojisi, siyasal bilim, deneysel iktisat ve başka alanlarda giderek artan kanıtlar insanların gerçekte işbirliğine yatkın ve diğerkâm olduğunu ya da en azından daha önceleri birçok iktisatçının ve başka düşünürün varsaydığından çok da az bencil davrandığını göstermiştir (Benkler, 2012, s. 17-19).

Bu bağlamda kolektif üretim, sözleşmelere ve piyasaya, şirketlere ve devlete dayalı üretimin yanında ortaya çıkmış sosyal bir üretim modelidir. Bu üretim biçimi, üç temel özellik ile temsil edilir. Bunlardan ilki gayrimerkeziliktir. Davranışta bulunma yetkisi, bir şirket yöneticisi ya da bir bürokrat gibi merkezi bir organizatörün ellerinde olmak yerine, karşısında davranış seçenekleri bulunan bireylere aittir. İkincisi ise, katılımcı bireylerin davranışlarını motive ve koordine etmek için para veya komutların değil, sosyal işaretlerin ve motivasyonların kullanılmasıdır (Benkler \& Nissenbaum, 2006). Son olarak yönetim ve idareye ilişkin organizasyonel yapı özel mülkiyet ya da sözleşme ilişkilerini temel almaz. Sürecin girdileri ve çıkıları müşterek unsurlar olarak ele alınır, organizasyonel idare ve yönetimsel kaynaklar ile görev tanımları ve tahsisleri ise özel mülkiyet ya da sözleşmelerin değil, katılımcı ve meritokratik modellerin kombinasyonlarından faydalanır (Benkler, 2016).

Sızıntı gazeteciliği de ağ mantığına dayalı, etkileşimli, kullanıcı denetimli ve gayrimerkezi bir mimariye sahiptir. Sızıntı platformuyla işbirliği yapmaya karar veren kaynak, mesajı gönderdikten sonra platformun sunduğu etkileşim olanakları sayesinde mesaj hakkında alıııla yeniden iletişime geçer ve ortam üzerinde iletişim sürecinin aktörleri işbirliği halinde mesaj üzerinde çalışır. Ağın 
herhangi bir düğümü sekteye uğratıldığında farklı düğümler ağa bağlanarak ya da düğümler kendini çoğaltarak ağ genişlemeye devam eder. Buradaki işbirliğini gerekli kılan ise sızıntıların yayınlanmasıyla ilgili ortaya çıkan, yüksek miktardaki verinin derlenmesi, belgelerde adı geçen ve zarar görebilecek kişi ve kurum isimlerinin redakte edilmesi ve bilgilerin bir bağlam içerisinde hikâyeleştirilerek halka ulaştırıması sorunudur. Kaynağın çoğunlukla medya dünyasının dışında olması ve sızıntıya konu olaylara ilişkin gazetecilik çalışmalarıyla ilgili siyasal bağlamı oluşturmada eksiklik yaşaması da bu işbirliğini gerekli kılan unsurlardan bir diğeridir.

Sızıntı gazeteciliğinde kaynağı sürece dâhil olmaya motive edense bir haksızlığın gerçekleştiğine ve bunun düzeltilmesi gerektiğine olan inancıdır ve bu motivasyon, kaynağın haksızlığı bildirmek için işbirliği yapmasında itici güç olur. Halkın yararına işbirliği yapma amacıyla gösterilen bu diğerkâm tutum bilgi uçurucunun sahip olması gereken bir karakterdir ve ancak bu karaktere sahip kaynakların harekete geçmesiyle sızıntı gazeteciliğinde bilgi akışı gerçekleşmeye başlar. Dolaysıyla, bilgi uçurucudan medya izleyicisine giden yolda sızıntıların elde edilmesi, gözden geçirilmesi, yayın hazırlanması ve yayınlanması sürecine ilişkin gazetecilik faaliyetleri ve sürece dâhil aktörlerin işbirliğine dayanan diğerkâm tutumlarıyla birlikte sızıntı gazeteciliği kolektif bir üretim biçimi olarak karşımıza çıkar.

\section{Sonuç}

Özetle bilgi uçurma, yakın siyasal tarihte güçlü kurumlar hakkındaki bilgileri kamuya açıklayarak insanları dışlayan, baskılayan, ezen ve sömüren asimetrik iktidarın gayretine bir karşı-güç oluşturmaya çalışmak için kullanılan bir eylem biçimi olmuştur. 1971'de Ellsberg'ün sızdırdığı Pentagon Dosyaları ABD hükümetinin Vietnam Savaşı'yla ilgili dezenformasyonunu açığa çıkararak devletin süreçleri hakkında güvensizlik oluşturmuş ve savaş karşıtı gösteriler ile kamuoyu baskısının yoğunlaşmasına sunduğu katkıyla Vietnam Savaşı'nın bitmesinde önemli bir rol oynamıştır. Bu süreçte halk nezdinde büyük bir itibar kaybeden Nixon, Watergate skandalının ardından görevinden istifa ederek ayrılan ilk ABD Başkanı olarak tarihe geçmiş, söz konusu sızıntılar Amerikalıların kendi siyasi sistemlerine yeni gözlerle bakmalarını sağlayarak siyasi etik ve gizli dinleme gibi konularda reformlara yol açmıştır. Cablegate sızıntılarının etkisini en güçlü Kuzey Afrika ve Ortadoğu coğrafyasında göstermiş, 2010 sonunda, Tunus Devrimi'yle sonuçlanacak halk ayaklanmasına yol açan olaylar için bir katalizör işlevi gören WikiLeaks, Tunus Cumhurbaşkanı Zeynel Abidin Binali'nin ülkeden kaçmasına, siyasal düzenin yeniden tesis edilmesine vesile olmuştur. Tunus'taki isyanın Mısır'a sıçramasıyla işsizlik, yoksulluk ve yolsuzlukları protesto etmek için otuz yıldır iktidarda olan Hüsnü Mübarek'e karşı gerçekleştirilen kitlesel eylemler esnasında Wikileaks'in Mübarek rejimini ve en yakın müttefiki ABD'yi zora sokacak Cablegate belgelerini yayınlaması ise Mübarek'in istifasını hızlandırmıştır. 
Cablegate sızıntılarının halka hızlı bir şekilde ulaşarak etkisini dünyanın genelinde göstermesini sağlayansa temel yapısını oluşturan ağ mantığından dolayı küresel, merkeziyetçi olmayan, açık, sınırsız, etkileşimli, kullanıcı denetimli ve altyapıdan bağımsız gibi ifadelerle anlatılabilecek olan temel karakteristik özelliklere sahip internet olmuştur. Bilgiyi meydana getirme ve paylaşmada işbirliğini kolaylaştıran yazılımlar açısından internetin yaşamış olduğu ve "Web 2.0" olarak tanımlanan teknik değişim yurttaş gazeteciliği olgusunun ortaya çıkmasına yardımcı olmuş, bu kavramdan doğan ve profesyonellerin ve amatörlerin gerçek hikâyeye ulaşmak için birlikte çalıştığı ağ gazeteciliği, halkın kitle kaynak, etkileşim, hiperbağlantı ve kullanıcılar tarafından oluşturulmuş içerikler aracılığıyla gazetecilik üretiminin her aşamasına dâhil olmasını sağlamış ve haber yapımını yukarıdan aşağıya doğrusal bir süreç olmaktan çıkararak işbirliğine dayalı hale getirmiştir. Ağ gazeteciliği böylece anaakım medya kuruluşlarının bağımsız, bireysel ve sosyal medya iletişiminin çok daha geniş ağı ile bağlantı kurmasını sağlamış, birey olarak gazeteci ile haber kuruluşlarının iş yapış biçimini değiştirmiştir. Günümüzde milyonlarca dijital belgenin depolanması için gereken maliyetlerdeki belirgin düşüş ve ağ faktörünün bilgiyi anında çoğaltılabilir ve yayılabilir hale getirmesi, devletlere ve şirketlere ait sırların saklanmasını oldukça iktidarın nasıl işlediğine, ne düşündüğüne ve ne yaptığına dair sürekli ve kapsamlı görünüm sunan bilgi sızıntıları, gazetecilik anlayışını ve pratiğini değiştirmiştir. Bir ağ içerisinde elde edilen bilgi sızıntılarının gazeteciler ve uzmanlar tarafından düzenlenerek, anaakım ve/veya alternatif medya kuruluşları aracılığıyla halka ulaştıııması süreci olarak tanımlanabilen sızıntı gazeteciliği de bugün yurttaş ve profesyonel gazeteci işbirliğiyle hayata geçirilen ağ gazeteciliği pratiğinin yenilikçi bir örneğini oluşturmuştur.

İktidarve halkarasındakiasimetrik güçilişkisini yurttaşlar lehine dengelemesi bağlamında sızıntı gazeteciliği deneyiminin ortaya çıkardığı iki temel sonuç vardır. Bunlardan ilki, bilgi sızıntılarının muktedirlerin iktidarlarını görünmez kılmak için halktan kitlesel olarak bilgi toplayarak ve onu sürekli gözetim altına tutarak tesis ettiği panoptik dünya kurgusuna karşı bir karşı-gözetim aracı, bilgi uçurucuların mahremiyetinin ise muktedirlerin baskısına karşı kendilerini korumak için kullandıkları bir öz savunma mekanizması olduğudur. Sızıntı gazeteciliği muktedir sınıflara karşı mücadele etmek ve iktidarı şeffaflaştırmak için bilgi yayınlayarak, asimetrik ekonomik ve siyasal iktidar ilişkilerine karşı direnenlerin girişimi olarak görülebilir. Internet üzerinde faaliyet gösteren bilgi sızdırma platformları, devasa mali güce ve etkiye sahip olan, böylece kendi operasyonlarının detaylarını, boyutlarını, mahiyetini ve sonuçlarını çoğunlukla gizleyebilme imkânını elinde bulunduran büyük şirketlerin ekonomik ve siyasal iktidarlarını, uyguladıkları baskı ve haksızlıkları görünür kılmışlardır. İnternetin birçok kişinin hayatını şekillendirdiği; bilgi, iletişim ve kolektif üretim için yeni bir kilit ortam haline geldiği; iktidarın panoptik gözünü genişlettiğini; fakat aynı zamanda normalde gözetimin objesi olanların gözlerini, kulaklarını ve seslerini muktedirlere yöneltmesini ve gözetimin gücünü tersine çevirmesini sağladığını günümüzde, birer karşı-gözetim unsuru olarak WikiLeaks ve diğer bilgi sızdırma platformları muktedir organizasyonlar 
hakkındaki bilgileri halka açması ve onları şeffaflaştırması öte yandan, yurttaşların, işçilerin ve tüketicilerin baskı altında tutulmasına karşı tahakküm altındakiler adına gerçekleştirilen bir öz savunma tepkisidir. Bu öz savunmanın araçları da Tor, Tails, PGP gibi mahremiyet güvencesi sağlayan uygulamalardır. íkinci sonuç ise bilgi sızıntılarının sızıntı gazeteciliğiyle halka ulaştıııması sürecinde, gazetecilik çalışmalarının ağ üzerindeki mevcut işbirliği olanaklarıyla kolektif bir üretim biçimini meydana getirdiğidir. Kolektif üretim ise sözleşmelere ve piyasaya, yönetimsel şirketlere ve devlete dayalı üretimin yanında ortaya çıkmış sosyal bir üretim modelidir ve gayrimerkezilik, sosyal motivasyon ve müştereklik temelinde temsil edilir. Bilgi uçurucudan medya izleyicisine giden yolda sızıntıların elde edilmesi, gözden geçirilmesi, yayına hazırlanması ve yayınlanması sürecine ilişkin gazetecilik faaliyetleri ve sürece dâhil aktörlerin işbirliğine dayanan diğerkâm tutumlarıyla birlikte sızıntı gazeteciliği kolektif bir üretim biçimi oluşturur.

\section{Kaynakça}

Beckett, C. (2010). The Value of Networked Journalism. The London School of Economics and Political Science.

Beckett, C. (2012). Wikileaks: partisan approach has plagued debate. Erişim 20 Ocak 2016, http://www.journalismfestival.com/news/charlie-beckett-partisanapproach-to-wikileaks-has-plagued-debate

Beckett, C., \& Ball, J. (2012). Wikileaks: News in the Networked Era. Cambridge: Polity Press.

Benkler, Y. (2016). Peer Production and Cooperation (yakında çıkacak). J. Bauer, \& M. Latzer (Dü) içinde, Handbook on the Economics of the Internet. Cheltenham \& Northampton: Elgar.

Benkler, Y. (2012). Penguen ve Leviathan: Iş̧birliğinin Kişisel Çıkar Karşısındaki Zaferi. (E. Kantemir, Çev.) İstanbul: Optimist Yayınları.

Benkler, Y., \& Nissenbaum, H. (2006). Commons-based Peer Production and Virtue. The Journal of Political Philosophy, 14 (4).

Bowman, S., \& Willis, C. (2003). We Media. Reston, VA: The Media Center at The American Press Institute.

Bruns, A., \& Highfield, T. (2012). Blogs, Twitter, and Breaking News: The Produsage of Citizen Journalism. R. A. Lind (Dü.) içinde, Produsing Theory in a Digital World: The Intersection of Audiences and Production in Contemporary Theory (s. 15-32). New York: Peter Lang Publishing Inc.

Buci-Glucksmann, C. (1980). Gramsci and the State. London: Lawrence and Wishart. 
Çalışkan, B. (2016). Ağ Toplumunda Bilgi Sızıntılarının Gazeteciliğe Etkisi: RedHack Örneği. Yayınlanmamış Doktora Tezi . İstanbul: Marmara Üniversitesi Sosyal Bilimler Enstitüsü.

Çalışkan, B. (2010). Yeni Illetişim Ortamlarında Gözetim: Üniversite Çalışanlarının Gözetim Algıları. Yeni Iletişim Ortamları ve Etkileşim Uluslararası Konferansı Bildiri Kitabı. İstanbul: Marmara Üniversitesi Illetişim Fakültesi.

Demiralp, M. (15 Ocak 2011). Tunus'ta ilk Arap halk devrimi! Erişim 15 Mart 2016, http://www.emekdunyasi.net/ed/guncel/10834-tunusta-ilk-arap-halk-devrimi

Dolgun, U. (2008). Şeffaf Hapishane Yahut Gözetim Toplumu: Küreselleşen Dünyada Gözetim, Toplumsal Denetim ve iktidar Illişkileri. İstanbul: Ötüken Neşriyat.

Duffy, M. J. (2011). Networked Journalism and Al-Jazeera English: How the Middle East Network Engages the Audience to Help Produce News. Journal of Middle East Media , 7 (1), 1-23.

Dünya Wikileaks'i bekliyor. Erişim 8 Mayıs 2016, http://haber.sol.org.tr/dunyadan/dunya-wikileaksi-bekliyor-haberi-36239

Ehrlich, J., \& Goldsmith, R. (Yönetenler). (2009). The Most Dangerous Man in America: Daniel Ellsberg and the Pentagon Papers [Sinema Filmi].

Fuchs, C. (2014). Social Media: A Critical Introduction. London: SAGE.

Gillmor, D. (2004). We the Media: Grassroots Journalism by the People, for the People. Sebastopol, CA: O’Reilly.

Glaser, M. (2010). Citizen Journalism: Widening World Views, Extending Democracy. In S. Allan (Ed.), The Routledge Companion to News and Journalism (pp. 578-590). Oxon: Routledge.

Hobbes, T. (1993). Leviathan: Bir Din ve Dünya Devletinin lçeriği, Biçimi ve Kudreti. (S. Lin, Çev.) İstanbul: Yapı Kredi Yayınları.

Jarvis, J. (5 Temmuz 2006). Networked journalism. Erişim 13 Ağustos 2015, http://buzzmachine.com/2006/07/05/networked-journalism

Jubb, P. B. (1999). Whistleblowing: A Restrictive Definition and Interpretation. Journal of Business Ethics , 21 (1), 77-94.

Jurrat, N. (2011). Mapping Digital Media: Citizen Journalism and the Internet. Erişim 17 Mayıs 2015, http://www.opensocietyfoundations.org/sites/default/ files/mapping-digital-media-citizen-journalism-and-internet-20110712.pdf

Kronoloji: Mısır Devrimi. Erişim 15 Mart 2016, http://staff.aljazeera.com.tr/kronoloji/kronoloji-misir-devrimi

Kwoka, M. B. (2015). Leaking and Legitimacy. Law Review, 48 (4), 1387-1456. 
Lovink, G. (30 Ağustos 2010). Ten Theses on Wikileaks. Erişim 11 Ocak 2016, http://networkcultures.org/geert/2010/08/30/ten-theses-on-WikiLeaks

Lyon, D. (1994). The Electronic Eye: The Rise of Surveillance Society. Minneapolis: University of Minnesota Press.

McCurdy, P. (2013). From the Pentagon Papers to Cablegate: How the Network Society Has Changed Leaking. B. Brevin, A. Hintz, \& P. McCurdy (Dü) içinde, Beyond WikiLeaks: Implications for the Future of Communications, Journalism and Society (s. 123-145). Hampshire: Palgrave Macmillan.

Pieterse, J. N. (2012). Leaking Superpower: WikiLeaks and the contradictions of democracy. Third World Quarterly, 33 (10), 1909-1924.

Poitras, L. (Yöneten). (2014). Citizenfour [Sinema Filmi].

Poulsen, K., \& Zetter, K. (10 Haziran 2010). 'I Can't Believe What I'm Confessing to You': The Wikileaks Chats. Erişim 2 Temmuz 2016, http://www.wired. com/2010/06/-wikileaks-chat

Reitman, J. (28 Şubat 2013). Bradley Manning Explains His Motives. Erişim 7 Şubat 2016, http://www.rollingstone.com/politics/news/bradley-manningexplains-his-motives-20130228

Roberts, P. (2014). Motivations for whistleblowing: Personal, private and public interests. A. J. Brown, D. Lewis, R. Moberly, \& W. Vandekerckhove (Dü) içinde, International Handbook on Whistleblowing Research (s. 207-229). Cheltenham: Edward Elgar.

Smith, A. (2010). Milletlerin Zenginliği. (H. Derin, Çev.) İstanbul: Yapı Kredi Yayınları.

Şahin, H. (2012). Kim Korkar Soruşturmacı Gazeteciden? Araştırmacı ve Soruşturmacı Gazetecilik: Dün, Bugün, Yarın. İstanbul: Say Yayınları.

Tietze, T. (11 Aralık 2010). Let me tell you a secret... WikiLeaks, the state and hegemony. Erişim 9 Mart 2016, http://left-flank.org/2010/12/11/let-me-tell-you-asecret-wikileaks-the-state-and-hegemony

Timisi, N. (2003). Yeni Illetişim Teknolojileri ve Demokrasi. Ankara: Dost Kitabevi. Tor: Overview. Erişim 15 Ocak 2016, https://www.torproject.org/-about/ overview.html.en

Uçkan, Ö. (17 Temmuz 2012). “Gri bölge"de renk körlügü: Hacktivizm, beyaz bereliler, basın özgürlüğü ve bilgi hakkı. Erişim 19 Ocak 2016, https://yenimedya. wordpress.com/2012/07/17/gri-bolgede-renk-korlugu-hacktivizm-beyaz-berelilerbasin-ozgurlugu-ve-bilgi-hakki

Uçkan, Ö. (4 Kasım 2011). Türkler, WikiLeaks sızıntıları karşısında üç maymunu oynuyor! Erişim 19 Ocak 2016, http://t24.com.tr/haber/turkler-wikileaks-sizintilarikarsisinda-uc-maymunu-oynuyor, 179597 
Uçkan, Ö., \& Ertem, C. (2011). Wikileaks: Yeni Dünya Düzenine Hoşgeldiniz. İstanbul: Etkileşim.

Wahlström, J. (Yöneten). (2013). Mediastan: A WikiLeaks Road Movie [Sinema Filmi].

What is Wikileaks? Erişim 3 Ağustos 2016, https://www.wikileaks.ch/About.html WikiLeaks:About. Erişim 3 Ağustos 2016, https://www.wikileaks.ch/wiki/WikiLeaks:About 